\author{
ANNA PENKAŁA-JASTRZĘBSKA \\ https://orcid.org/0000-0001-6386-8139 \\ Uniwersytet Pedagogiczny im. Komisji Edukacji Narodowej w Krakowie
}

\title{
MIT SREBRNEJ ŁYŻECZKI? PRZEDMIOTY PRESTIŻOWE W SZLACHECKICH INWENTARZACH MAJĄTKOWYCH Z KSIĄG GRODZKICH WOJEWÓDZTWA KRAKOWSKIEGO W CZASACH SASKICH*
}

\begin{abstract}
Abstrakt: Podjęta analiza ma na celu próbę charakterystyki i określenie skali wzmiankowania przedmiotów świadczących o prestiżu właścicieli w szlacheckich inwentarzach pośmiertnych z pierwszej połowy XVIII w. W ramach podjętych badań przestudiowano, w jaki sposób rzeczywiście postrzegano prestiż w kręgach magnackich oraz na ile średnia i uboższa szlachta - której inwentarze dominują $\mathrm{w}$ analizowanym materiale źródłowym - inspirowała się i wzorowała na stylu życia najzamożniejszych. Szczegółowa analiza zachowanych źródeł tego typu jest przyczynkiem do scharakteryzowania szlacheckiego standardu życia i próbą wyznaczenia rangi, jaką w szlacheckim świecie wiązano z posiadaniem określonych mobiliów.

Słowa kluczowe: kultura materialna, inwentarz, rejestr pośmiertny, czasy saskie, księgi grodzkie, prestiż społeczny.
\end{abstract}

Abstract: The analysis conducted here is an attempt to characterize and determine the scale of references made to objects conferring prestige on their owners in noble post-mortem inventories from the first half of the eighteenth century. The autor has examined how prestige was regarded in magnate circles and to extent to which the middle and lower nobility - whose inventories dominate in the analysed source material - imitated the lifestyle of the most wealthy. A thorough analysis of the preserved sources is a contribution to the characterization of the standard of living of the nobility and an attempt to determine the importance attached to the possession of certain kinds of movable property.

Keywords: material culture, inventory, post-mortem register, Saxon period, borough records, social prestige.

* Artykuł powstał w wyniku badań prowadzonych w ramach grantu Narodowego Centrum Nauki pt. „Dobrodziejki i klienci. Specyfika patronatu kobiecego i relacji klientalnych w czasach saskich", nr rej. 2015/19/B/HS3/01797. 
Badania podejmujące zagadnienie polityki prestiżu wymagają analizy różnorodnych aspektów ujawniających szlacheckie ambicje - w tym sfery kultury materialnej. Przedmioty wykazywane w inwentarzach mobiliów należących do osób ze stanu szlacheckiego mogą bowiem stanowić wartościowe źródło, ujawniające tendencje do pozyskiwania i gromadzenia określonych dóbr, nie tyle ze względów praktycznych, ile wyłącznie ambicjonalnych ${ }^{1}$. W toku dociekań, mających na celu określenie poziomu zamożności przedstawicieli rodzin szlacheckich w dawnej Rzeczypospolitej, łatwo ulec mitowi reprezentacji owej „srebrnej łyżeczki”, a więc nadmiernemu wartościowaniu pojedynczych mobiliów, mających być nośnikami szczególnej wartości i wyznacznikami przynależności do warstwy posiadającej ${ }^{2}$. Zasadne wydaje się zatem ustalenie, czy posiadanie choćby kilku drobnych przedmiotów wykonanych z cennych kruszców mogło być traktowane jako synonim luksusu, osiągnięcia określonej pozycji materialnej, a nawet pewnego wyróżnika pozycji społecznej przedstawicieli osiemnastowiecznej szlachty ${ }^{3}$. W odniesieniu do szlacheckich

${ }^{1}$ Zob. L. Białkowski, o znaczeniu ksiag grodzkich dla historii obyczajów i kultury materialnej, w: Pamiętnik IV Powszechnego Zjazdu Historyków Polskich w Poznaniu 6-8 XII 1925, t. 1: Referaty, Poznań 1925; Historia kultury materialnej Polski w zarysie, t. 4: Od połowy XVII do końca XVIII wieku, red. Z. Kamieńska, B. Baranowski, Wrocław 1978.

${ }^{2}$ Pojedyncze elementy zastawy stołowej bywały jedynymi wartościowymi przedmiotami wykazanymi w rejestrze, umieszczonymi na samym początku spisu (podobnie jak pojedyncze srebrne guzy przytwierdzone do różnych elementów garderoby czy pojedyncze egzemplarze srebrnej lub złotej biżuterii). Wyeksponowanie tych elementów miało dawać poczucie, że ich właściciel zasłużenie mianował się szlachcicem, ponieważ stać go było na sprawienie sobie choćby kilku wartościowych mobiliów; rzeczywista wartość owych elementów częstokroć była jednak znacznie niższa z uwagi na ich stan zachowania i sposób wykonania, zob. A. Penkała, Panieńskie ochędóstwo. Kwestie posagowe i wienne w małżenstwach szlachty województwa krakowskiego w czasach saskich, Kraków 2016, s. 337. $\mathrm{Na}$ funkcjonowanie mitu srebrnej łyżeczki w kontekście popularności występowania sreber stołowych w inwentarzach szlacheckich zwracali już uwagę: A. Pośpiech, Srebrna łyżka - probierz szlacheckiej zamożności? (Przykład Wielkopolski XVII wieku), w: Nędza i dostatek na ziemiach polskich od średniowiecza po XX wiek, red. J. Sztetyłło, Warszawa 1992, s. 151162; J. Dumanowski, Świat rzeczy szlachty wielkopolskiej w XVIII wieku, Toruń 2006, s. 82.

${ }^{3}$ Konieczność podjęcia takich badań postulowali już: A. Roćko, Sarmacki świat wartości materialnych $w$ XVIII wieku. Zarys problematyki, w: Codzienność i niecodzienność oświeconych, t. 1: Przyjemności, pasje i upodobania, red. B. Mazurkowa, Katowice 2013, s. 11-22; T. Zielińska, Kosztowności jako składnik wyposażenia kobiet w XVII i XVIII wieku, w: Miasto region - społeczeństwo. Studia ofiarowane Profesorowi Andrzejowi Wyrobiszowi w sześćdziesiąta rocznice Jego urodzin, red. E. Dubas-Urwanowicz, J. Urwanowicz, Białystok 1992, s. 300302; B. Popiołek, Manelek dwie i pereł sznurów cztery. O szlacheckich inwentarzach posagowych i pośmiertnych z XVIII wieku, „Annales Academiae Paedagogicae Cracoviensis. Studia Historica" 4, 2005, s. 168. Fundamentalną pracą, w której podjęty został trud oszacowania rzeczywistej wartości przedmiotów wzmiankowanych w osiemnastowiecznych 
realiów określenie polityki prestiżu rozumiane jest jako chęć manifestowania określonych postaw, zachowań i wartości składających się na budowanie pożądanego wizerunku ${ }^{4}$. W przypadku szlachty gromadzenie przedmiotów uznawanych za prestiżowe mogło być więc sposobem na podkreślenie statusu, stanu posiadania, a wreszcie pozycji społecz$n j^{5}$. Znaczenie analizowanego materiału źródłowego warunkowane jest zarówno przez liczbę zachowanych inwentarzy szlacheckich, jak i przez ich różnorodność - począwszy od prostych i okrojonych rejestrów majątkowych inwentaryzujących określony rodzajów przedmiotów, po rozbudowane rejestry pośmiertne, oddające cały stan posiadania zmarłego ${ }^{6}$. Zdarzało się, że inwentarze ruchomości stanowiły również część

inwentarzach, jest monografia Andrzeja Pośpiecha, Pułapka oczywistości. Pośmiertne spisy ruchomości szlachty wielkopolskiej z XVII wieku, Warszawa 1992. Do znaczących badań w tym zakresie należą również ustalenia Jarosława Dumanowskiego, Świat rzeczy.

${ }^{4}$ Szerzej o definiowaniu pojęcia prestiżu: H. Domański, Stratyfikacyjne funkcje prestiżu, „Przegląd Socjologiczny” 68, 2019, 2, s. 187-208. Bożena Popiołek zwracała uwagę, że na szlachecką politykę prestiżu składało się dokładanie starań, aby jak najszerzej rozpowszechniać informacje o wszelkich wydarzeniach związanych z życiem rodziny, angażujących spore środki finansowe (uroczystości prywatne, ingresy, bale, polowania), eadem, Z kraju i ze świata. Krakowskie nowiny rękopiśmienne z 1729 r. jako źródło do historii mentalności społeczeństwa czasów saskich, „Rocznik Historii Prasy Polskiej” 15, 2012, 1 (29), s. 28. Jacek Pielas jako prestiżowe określał te z przedmiotów znajdujących się w szlacheckich inwentarzach, których posiadanie nie było w żaden sposób konieczne, a jedynie pożądane przez określoną grupę społeczną, idem, Podziały majątkowe szlachty koronnej w XVII wieku, Kielce 2013, s. 10. Wykazanie w spisie określonych ruchomości, których wartość miała wpływać na postrzeganie ich posiadacza, akcentowała również Teresa Zielińska, Kosztowności, s. 300. Jako prestiżowe uznawano także te przedmioty lub dobra, które określona część społeczeństwa chciałaby posiadać lub konsumować, jednak z uwagi na ich cenę i trudność pozyskania były one zarezerwowane wyłącznie dla wąskiej grupy społecznej, zob. A. Wyczański, Studia nad konsumpcją żywności w Polsce w XVI i pierwszej połowie XVII w., Warszawa 1969, s. 6.

${ }^{5} \mathrm{Na}$ charakterystyczny układ szlacheckich inwentarzy zwracała uwagę Urszula Kicińska, podkreślając szczególny dla tego typu źródeł schemat zapisu - od rzeczy najwartościowszych (jak biżuteria, zegary czy broń) po przedmioty o mniejszym znaczeniu, zob. eadem, Splendory domowe w staropolskich inwentarzach ruchomości, KHKM 65, 2017, 4, s. 461-470. Na zjawisko „polityki prestiżu” wyrażanej poprzez posiadanie określonych przedmiotów zwracał uwagę Dumanowski, wnioskując, że była ona wyrazem szlacheckiej „przyjemności posiadania”, idem, Inwentarze wielmożnych i urodzonych. Konsumpcja szlachty wielkopolskiej w XVIII w., KHKM 51, 2003, 2, s. 261-276. Badacz podkreślał również, że z uwagi na specyfikę analizowanego materiału źródłowego rzeczywista wartość wykazywanych w inwentarzach rzeczy jest niezwykle trudna do wykazania, idem, Świat rzeczy, s. 286-288. Wiele rzeczy traktowanych jako elitarne wymienia też Agata Roćko, Sarmacki świat wartości, s. 11-22.

${ }^{6}$ Ważne i różnorodne badania ukazujące znaczenie szlacheckich inwentarzy prowadzili już m.in: J. Dumanowski, Inwentarze wielmożnych, s. 261-276; idem, Przepych 
testamentu, spisywaną najczęściej wraz z dyspozycją określającą komu i w jakiej liczbie określone mobilia mają zostać przekazane po śmierci właściciela ${ }^{7}$. W odniesieniu do badanego materiału źródłowego można jednak stwierdzić, że jedynie część testamentów wprowadzonych do krakowskich ksiąg testamentów zawierała tego rodzaju zapisy. Znacznie częściej spisane w ten sposób dyspozycje ograniczały się wyłącznie do rozdziału określonych sum pieniężnych, natomiast rejestr mobiliów wprowadzany był do ksiąg jako osobny dokument (często jako kolejny wpis, następujący zaraz za testamentem). Należy również podkreślić, że w analizowanym materiale źródłowym nawet w przypadku dołączenia spisu do testamentu widoczne są stosowane uogólnienia - konkretnej dyspozycji podlegały przede wszystkim rzeczy najwartościowsze, pozostałe zaś wpisywano jedynie jako przedmioty „pozostałe” lub „niespecyfikowane”. Osobne inwentarze pośmiertne były pod tym względem bardziej detaliczne. Mobilia wzmiankowane w pełnych spisach ruchomości przypisać można do kilku podstawowych grup, które powtarzają się w większości zachowanych źródeł ${ }^{8}$ W szlacheckich rejestrach regularnie ujmowano odzież, biżuterię oraz przedmioty codziennego użytku - dodatkowo rozdzielane ze względu na surowiec, z jakiego zostały wykonane. Ponadto, do inwentarzy włączano elementy wyposażenia wnętrz, przedmioty osobiste oraz konie i inne zwierzęta hodowlane. Przedmioty należące do każdej ze wzmiankowanych grup mogły wskazywać na poziom zamożności ich właściciela, uwydatniany poprzez dążenie do zgromadzenia rzeczy

i tezauryzacja. Biżuteria $w$ inwentarzach ruchomości szlachty wielkopolskiej w XVIII wieku, w: Biżuteria w Polsce. Treści, teksty, przesłania, red. K. Kuczwajd, Toruń 2005, s. 51-60; R.E. Mohrmann, Pośmiertne inwentarze mienia - krytyka źródła, problemy badawcze, KHKM 53, 2005, 2, s. 137-146; A. Pośpiech, Majątek osobisty szlachcica w świetle wielkopolskich pośmiertnych inwentarzy ruchomości z XVII wieku, KHKM 29, 1981, 4, s. 463-482; D. Główka, A. Klonder, Inwentarze mienia $w$ badaniach kultury Europy od średniowiecza po nowożytność, KHKM 51, 2003, 2, s. 157-176; B. Bieńkowska, Inwentarze księgozbiorów prywatnych jako źródła do badań nad dziejami czytelnictwa, „Studia o Książce” 18, 1989, s. 65-76; A.R. Chodyński, Obyczajowość polska w świetle inwentarzy Czapskich herbu Leliwa z pierwszej połowy XVIII wieku, KHKM 51, 2003, 2, s. 277-290.

${ }^{7}$ Wiele tego rodzaju przykładów można odnaleźć wśród opracowań źródłowych, zob. Testamenty szlachty krakowskiej XVII-XVIII w. Wybór tekstów źródłowych z lat 1650-1799, wyd. A. Falniowska-Gradowska, Kraków 1997; Cui contingit nasci, restat mori. Wybór testamentów staropolskich z województwa sandomierskiego, oprac. M. Lubczyński, J. Pielas, H. Suchojad, Warszawa 2005; Testamenty szlacheckie z ksiag grodzkich wielkopolskich z lat 1631-1655, wyd. P. Klint, Poznań-Wrocław 2008 (Źródła Dziejowe, t. 27); Testamenty szlacheckie z ksiag grodzkich wielkopolskich 1657-1680, wyd. P. Klint, Wrocław 2011 (Źródła Dziejowe, t. 28); B. Popiołek, Woli mojej ostatniej testament ten... Testamenty staropolskie jako źródło do historii mentalności XVII i XVIII wieku, Kraków 2009.

${ }^{8}$ Por. J. Dumanowski, Świat rzeczy, s. 14-16. 
modnych, prestiżowych i charakteryzujących się wysokim poziomem wykonania. Rejestry różniła naturalnie również liczba wzmiankowanych rzeczy, a w przypadku biżuterii i przedmiotów użytkowych - przewaga surowca, z jakiego zostały wykonane. Różnicowały je ponadto szczere wzmianki o rzeczywistym stanie zachowania inwentaryzowanych przedmiotów - w sposób znaczący przekładającym się na ich faktyczną wartość.

Analiza zachowanych inwentarzy z krakowskich ksiąg grodzkich stanowi kolejny etap w badaniach mających na celu określenie szlacheckiego standardu życia i wyznaczenie rangi, jaką w szlacheckim świecie wiązano z posiadaniem określonych przedmiotów. Podstawę źródłową badań stanowi obszerny materiał archiwalny liczący 306 inwentarzy pośmiertnych, wprowadzonych do krakowskich ksiąg grodzkich w latach 1701-17639. Wśród badanej bazy źródłowej przeważają inwentarze męskie, które stanowią aż 74,5 proc. zebranego materiału.

Tabela 1. Inwentarze z krakowskich ksiąg grodzkich - zestawienie ilościowe

\begin{tabular}{|c|c|c|c|}
\hline & $\begin{array}{c}\text { Liczba } \\
\text { odnalezionych } \\
\text { inwentarzy }\end{array}$ & $\begin{array}{c}\text { Liczba spisów zawierających } \\
\text { choć jeden przedmiot ze } \\
\text { szlachetnego kruszcu }\end{array}$ & $\begin{array}{c}\text { Liczba spisów } \\
\text { niezawierających } \\
\text { przedmiotów wartościowych }\end{array}$ \\
\hline $\begin{array}{c}\text { Inwentarze } \\
\text { męskie }\end{array}$ & 228 & 197 & 31 \\
\hline $\begin{array}{c}\text { Inwentarze } \\
\text { kobiece }\end{array}$ & 78 & 62 & 16 \\
\hline
\end{tabular}

Spośród wszystkich odnalezionych rejestrów aż 259 inwentarzy (84,6 proc.) poświadcza posiadanie przez zmarłego przynajmniej jednego przedmiotu wykonanego ze szlachetnego kruszcu. W pozostałych przypadkach miejsce srebrnych i złotych elementów zajmowała zastawa drewniana, a w spisie przeważały naczynia cynowe i miedziane oraz proste, często również podniszczone przedmioty codziennego użytku, nieprzedstawiające żadnej znaczącej wartości.

W celach porównawczych dokonano również podziału spisów zawierających przedmioty wartościowe na lata, w jakich wpisy wprowadzano do ksiąg grodzkich.

${ }^{9}$ Należy zaznaczyć, że w XVIII w. województwo krakowskie dzieliło się na kilka powiatów administracyjnych. W czasach saskich w skład województwa wchodziły następujące powiaty: krakowski, lelowski, proszowicki, ksiąski, sądecko-czchowski, biecki i śląski. Sąd krakowski, którego księgi stanowią podstawę źródłową artykułu, obejmował teren powiatu ziemskiego krakowskiego oraz powiaty lelowski, proszowicki i ksiąski. Zob. A. Penkała, Panieńskie ochędóstwo, s. 34. 
Tabela 2. Inwentarze z krakowskich ksiąg grodzkich - zestawienie spisów zawierających przedmioty wartościowe z podziałem na lata wprowadzenia rejestru do księgi

\begin{tabular}{|c|c|c|c|c|}
\hline Lata & $\begin{array}{c}\text { Liczba spisów } \\
\text { zawierających } \\
\text { przedmioty } \\
\text { wartościowe } \\
\text { (męskie) }\end{array}$ & $\begin{array}{c}\text { Udział } \\
\text { procentowy } \\
\text { spisów } \\
\text { zawierających } \\
\text { przedmioty } \\
\text { wartościowe } \\
\text { (męskie) }\end{array}$ & $\begin{array}{c}\text { Liczba spisów } \\
\text { zawierających } \\
\text { przedmioty } \\
\text { wartościowe } \\
\text { (kobiece) }\end{array}$ & $\begin{array}{c}\text { Udział } \\
\text { procentowy } \\
\text { spisów } \\
\text { zawierających } \\
\text { przedmioty } \\
\text { wartościowe } \\
\text { (kobiece) }\end{array}$ \\
\hline $1701-1710$ & 19 & 95 & 8 & 80 \\
\hline $1711-1720$ & 30 & 85,7 & 8 & 88,8 \\
\hline $1721-1730$ & 24 & 80 & 9 & 64,2 \\
\hline $1731-1740$ & 24 & 75 & 11 & 91,6 \\
\hline $1741-1750$ & 33 & 86 & 10 & 66,6 \\
\hline $1751-1760$ & 36 & 90 & 7 & 87,5 \\
\hline $1761-1773$ & 31 & 93 & 9 & 90 \\
\hline
\end{tabular}

Zauważalny spadek liczby inwentarzy poświadczających posiadanie cennych przedmiotów widoczny jest w latach 1721-1740, a w przypadku spisów kobiecych także w latach 1741-1750. Można odnaleźć pewne analogie w badaniach prowadzonych na inwentarzach szlachty wielkopolskiej przez Jarosława Dumanowskiego, który również odnotował spadek liczby przedmiotów luksusowych po $1720 \mathrm{r}$. w porównaniu do początku stulecia. Wytłumaczeniem zjawiska miała być zmiana postrzegania przedmiotów wykonanych z cennych kruszców, które jeszcze na początku XVIII w. miały być traktowane jako swoista lokata kapitału i zabezpieczenie na trudne lata ${ }^{10}$. W opracowaniu dotyczącym szlachty wielkopolskiej brak jednak analizy przeprowadzonej w pełnych przedziałach czasowych, pozwalających uchwycić cały wiek XVIII (opublikowane dane odnoszą się do lat 1699-1719, następnie zaś 1740-1760 i 1779-1793), co uniemożliwia wyczerpujące porównanie osiągniętych rezultatów. W przypadku szlachty krakowskiej spisy wprowadzane do ksiąg po 1750 r. nie tylko częściej wzmiankują posiadanie przez zmarłych pojedynczych przedmiotów wartościowych, ale również wskazują na podniesienie się ogólnego standardu życia szlachty. Rejestry ze wskazanego okresu (1750-1773) są zauważalnie bardziej rozbudowane, a liczba przedmiotów cennych znacząco wzrasta. Wzmiankowane przedmioty opisywane są też znacznie bardziej skrupulatnie, często z określeniem ich pochodzenia i opisem

10 Por. J. Dumanowski, Świat rzeczy, s. 295. 
detali (użytych materiałów, zastosowanych zdobień). Ze scharakteryzowanego wyżej materiału źródłowego przedmiotem szczegółowych badań stały więc się jedynie te spisy, które ujmowały przedmioty wartościowe i to na ich podstawie wykazano elementy powszechne i powtarzalne, przy jednoczesnym podaniu przykładów przedmiotów szczególnie pożądanych, które mogą zostać zaklasyfikowane jako rzeczy o charakterze prestiżowym. Z uwagi na powtarzalność zapisów poświadczających posiadanie przez przedstawicieli szlachty krakowskiej rzeczy popularnych, takich jak elementy srebrnej zastawy stołowej, pojedyncze egzemplarze biżuterii czy elementy uzbrojenia, w niniejszym opracowaniu wykorzystane zostały fragmenty 49 wybranych rejestrów, traktowanych jako egzemplifikacja omawianych zjawisk.

Zachowane źródła cechują się różnym stopniem precyzji zapisów - od rejestrów pośmiertnych, których autorzy skoncentrowani byli wyłącznie na wykazaniu przedmiotów posiadających największą wartość - najczęściej kosztowności lub odzieży, po skrupulatne spisy mobiliów, ujmujące zachowany majątek w sposób możliwie dokładny, niepomijające przy tym rzeczy nawet o znikomej wartości. W celu ukazania szlacheckich dążeń do zgromadzenia szczególnie cennych czy modnych przedmiotów, wykorzystane zostały przede wszystkim liczne wzmianki o kosztownościach, biżuterii, przedmiotach rzadkich i drogich, a także ruchomościach stanowiących przejawy aktualnej mody, ujawniającej się poprzez nabywanie popularnych wówczas przedmiotów użytkowych. Należy jednak zaznaczyć, że w prezentowanym zestawieniu pominięta została sfera ubiorów, na którą składają się rozległe wykazy licznych elementów garderoby znajdującej się w szlacheckich kufrach i szafach. Z uwagi na liczbę wzmiankowanych przedmiotów, ich różnorodność, widoczne wpływy kulturowe, szeroką reprezentację towarów o zróżnicowanej proweniencji, a także kwestię oszacowania wartości wzmiankowanych elementów garderoby, zagadnienie to winno stać się przedmiotem osobnego, gruntownego opracowania. Uwzględniając specyfikę materiału źródłowego należy też zaznaczyć, że jedynie nieliczne rejestry posiadają adnotację co do szacowanej lub rzeczywistej wartości wymienionych przedmiotów, pozostawioną przez autora spisu ${ }^{11}$. Przesłanką do wartościowania

11 Szacowaną cenę przedmiotów podawano w momencie ich inwentaryzowania, zgodnie z posiadaną wiedzą. Rzeczywistą wartość weryfikowali złotnicy, jubilerzy, kuśnierze i inni rzemieślnicy, zdolni ocenić ich jakość i autentyczność. Wielokrotnie zdarzało się, że dopiero podczas takiej oceny odkrywano znikomą wartość rzekomych klejnotów, dotąd uznawanych za wysadzane prawdziwymi kamieniami szlachetnymi. W rejestrze Barbary 1 voto Księskiej 2 voto Dębinskiej wprost zaznaczono, że z taksowanych rzeczy została tylko „rubinowa wstążka z zausznicami rubinowymi za dwieście 
zinwentaryzowanych obiektów są więc kruszce i surowce, z jakich zostały one wykonane, wzmianki o wysadzaniu ich kamieniami szlachetnymi czy dopiski autora inwentarza poświadczające, iż są to przedmioty „nowe” lub „teraz kupione”. Ponadto, w przypadku rejestrów majątków szlachty średniozamożnej i uboższej, elementy najcenniejsze zazwyczaj umiejscawiano na początku wykazu, poświęcając im najbardziej skrupulatny opis.

Pośród najcenniejszych przedmiotów wzmiankowanych w pośmiertnych inwentarzach dominuje biżuteria wykonana $\mathrm{z}$ najcenniejszych kruszców i oprawiana drogocennymi kamieniami ${ }^{12}$. Nawet w najskromniejszych rejestrach znaleźć można proste manelki, zausznice czy łańcuszki. Podobnie jak w przypadku rejestrów majątkowych szlachty wielkopolskiej, także i tutaj wykazać można skłonność do większej drobiazgowości w przypadku opisywania cennych mobiliów ${ }^{13}$. Przy tym nie tylko ilość biżuterii podkreślała status posiadacza - zamożni pozyskiwali precjoza o oryginalnej formie, dodatkowo wysadzane cennymi kamieniami szlachetnymi ${ }^{14}$. Najpowszechniej reprezentowane były przedmioty ozdabiane diamentami - w ilości od kilku do kilkudziesięciu szlachetnych kamieni zdobiących jeden element biżuterii ${ }^{15}$. Ponadto, $w$ rejestrach często pojawiały się obiekty zdobione krwawnikami ${ }^{16}$, rubinami i turkusami - powszechnie upiększano nimi pierścienie, manele, a nawet proste łańcuchy. Zaledwie kilka rejestrów szlacheckich - i to pozostałych po stosunkowo zamożnej szlachcie urzędniczej - poświadcza posiadanie i użytkowanie bursztynów ${ }^{17}$.

pięćdziesiąt złotych, insze klejnoty były fałszywe i tam się zostały u tych Żydów", ANK, Oddział I (dalej: ANK I), Acta Castrensia Cracoviensia Relationes (dalej: CastrCracRel) 139, „Oblata inventarii rerum mobilium M. Marianna de Krasielice Dembinska propriarum" s. 157.

12 Szerzej o wartości szlacheckiej biżuterii i popularności określonych typów ozdób: J. Dumanowski, Przepych i tezauryzacja, s. 53-55; M.B. Toczyńska, o biżuterii oświeconych uwag kilka, w: Codzienność i niecodzienność oświeconych, t. 1, s. 111; A. Roćko, Sarmacki świat wartości, s. 11-22; T. Zielińska, Kosztowności, s. 300.

13 Zob. J. Dumanowski, Świat rzeczy, s. 223.

${ }^{14}$ Zob. B. Popiołek, Manelek dwie, s. 168; por. S. Życiński, Złotnictwo w skarbcach magnatów i szlachty polskich ziem koronnych w Rzeczypospolitej XVII-XVIII wieku. Broń biała, rzędy końskie, srebra, klejnoty, Szczecin 1990, s. 147-148.

15 ANK I, CastrCracRel 129, „Oblata inventarii rerum mobilium morte Gnosi Trewani”, s. 1295.

${ }^{16}$ Krwawnik - inaczej karneol; minerał będący odmianą chalcedonu, występujący w barwach od ciemnoczerwonej do żółtej, zob. I. Turnau, Słownik ubiorów. Tkaniny, wyroby pozatkackie, skóry, broń i klejnoty oraz barwy znane w Polsce od średniowiecza do początku XIX w., Warszawa 1999, s. 84.

17 Zob. ANK I, CastrCracRel 135B, „Oblata inventarii rerum olim Mci Tęgoborski Captnei Małogosten derelict”, s. 2403; ibidem, CastrCracRel 197, „Regestr mobilii jako to 
W rejestrach zamożnej i uboższej szlachty wyraźnie widoczne są duże dysproporcje pod względem liczby cennych przedmiotów. Podczas gdy ci pierwsi mogli sobie pozwolić na zgromadzenie całej kolekcji biżuterii wysadzanej różnymi rodzajami kamieni szlachetnych, w rejestrach drugiej grupy zapisy sprowadzają się do prostych wzmianek poświadczających posiadanie pojedynczych klejnocików. Przykładem tak prowadzonego rejestru może być inwentarz spisany po śmierci Elżbiety Gostkowskiej, wprowadzony do ksiąg grodzkich w 1704 r. W majątku szlachcianki znajdował się zaledwie „pierścień z diamencikami” oraz „sztuczka maleńka z rubinkiem jednym” ${ }^{18}$. Wskazane przedmioty były

klejnotów, srebra, cyny, miedzi, garderoby, stada, cugów, karet, biblioteki i innych różnych rzeczy, tudzież krescencyi w snopiu różnego ziarna y in natura pozostałych zbóż w spiklerzach, słodów, gorzałek, bydła, owiec, trzody i naczynia gospodarskiego, pieniędzy nie tylko w skarbie ale i prowentach po śmierci S.P Jaśnie Wielmożnego JMci Pana Adama na Zakliczynie Jordana kasztelana woynickiego, Generała Lithuenanta Woysk Koronnych J.K Mci y Rzeczypospolitey, Kawalera Orderu Orła Białego, niegdyś Jaśnie Wielmożnej JejMci Pani z Książąt Lubomirskich Jordanowy, Kasztelanowy Wojnickiej pozostałej wdowy męża, cum specificis adnotationibus w którym miejscu się znajduje w roku 1764 tym opisany”, b.pag. Kategorię „szlachty urzędniczej” w pierwszej połowie XVIII w. wydzielić można z uwzględnieniem dwóch kryteriów: pierwsze to sprawowanie lokalnych urzędów ziemskich na określonym terytorium przez przedstawicieli wybranych rodzin, co wpływało na koncentrowanie podejmowanych przez nich działań na tymże obszarze. Drugim kryterium pozostawał fakt posiadania majątku ziemskiego na terenie wybranego województwa, a więc związanie interesów przedstawicieli określonych rodzin szlacheckich z tym właśnie obszarem, zob. Z. Góralski, Urzędy i godności $w$ dawnej Polsce, Warszawa 1984; S. Ciara, Senatorowie i dygnitarze koronni $w$ drugiej połowie XVII wieku, Wrocław 1990, s. 18. Dotychczasowe badania pozwoliły wykazać, że grupa szlachty urzędniczej miała znacznie większe możliwości finansowe, niż grupa szlachty średniej i uboższej, zob. T. Zielińska, Rody urzędami zaszczycone. Próba sondażu, w: Społeczeństwo staropolskie. Studia i szkice, t. 2, red. A. Wyczański, Warszawa 1979, s. 200. Co znaczące, w dążeniu do zaakcentowania swej pozycji społecznej część przedstawicieli wskazanej grupy decydowała się na decyzje o charakterze majątkowym, których konsekwencje przekraczały ich realne możliwości, zob. A. Penkała, Panieńskie ochędóstwo, s. 94-95. Członkowie tej grupy mieli też wyższe aspiracje, uwidaczniane we wspomnianej wyżej „polityce prestiżu” realizowanej poprzez posiadanie określonych typów mobiliów - ma to znaczenie w badaniu szlacheckich inwentarzy, podobnie jak fakt występowania w tego rodzaju spisach kategorii przedmiotów nienotowanych wśród szlachty nieposiadającej urzędów, jak choćby wspomniane dalej sygnety, zob. ANK I, CastrCracRel 133, „Oblata Inventarii rerum mobilium morte ol. G. Dobinska derelicte”, s. 395; ibidem, CastrCracRel 135, „Oblata regestri alimentorum morte M. Dąbski derelictarum”, s. 1539. Na zasadność wyróżnienia regestrów osób pełniących świeckie urzędy czy dzierżących kościelne godności, w związku z ich znacznie większymi możliwościami finansowymi wskazywał już Jarosław Dumanowski, Świat rzeczy, s. 108.

18 ANK I, CastrCracRel 131, „Oblata inventarii rerum morte Gostkowska relict.”, s. 136. 
jedynymi stosunkowo kosztownymi elementami biżuterii, które ujęto w pośmiertnym spisie. Dla części uboższej szlachty znacznie trudniejsza była też droga, pozwalająca wejść w posiadanie choćby pojedynczych przedmiotów jubilerskich. Podczas gdy w rejestrach zamożnych wzmiankowano całe komplety biżuterii - otrzymanej od rodziców i krewnych, podarowanych sobie wzajemnie bądź kupionych w trakcie małżeństwa to w inwentarzu z 1705 r., spisanym po wojskim halickim Krzysztofie Modrzewskim $^{19}$, jego żona wprost wskazała, że po śmierci męża mogła zostawić sobie zaledwie jeden pierścionek diamentowy, „którym sobie z nabycia pracy mojej kupiła"20. Zupełnie odmienny charakter miał pochodzący z tego samego okresu (1706) rejestr pośmiertny, będący spisem majątku po miecznikowej krakowskiej Annie z Ligęzów Szembekowej ${ }^{21}$. W inwentarzu wymieniono wiele różnych rodzajów klejnotów - od wstęg szmaragdowych, liczących po kilkadziesiąt sztuk kamieni szlachetnych, po wymyślne formy biżuterii przypominającej róże, pająka z łezkami czy zausznice uformowane na kształt gruszy. Wszystkie elementy wysadzane były licznymi diamentami, turkusami i perłami ${ }^{22}$. Sporządzenie detalicznego rejestru ruchomości było więc sposobem na uwypuklenie elementów mających potwierdzać szlachecki status zmarłego ${ }^{23}$.

Dla kobiet z rodzin szlacheckich do podkreślenia poziomu zamożności służyła nie tylko ilość, ale i rodzaj noszonej biżuterii. W kobiecych inwentarzach odnotowywano precjoza wykonane z pereł, wydzielając pośród

${ }^{19}$ Krzysztof z Garbar Modrzewski (zm. przed 1686) - wojski halicki; pierwszy małżonek Marianny z Łodzińskich. Po jego śmierci Marianna wyszła za mąż za Krzysztofa Dobińskiego (zm. 1718).

20 ANK I, CastrCracRel 132, „Oblata connotationis rerum mobilium morte Modrzewski derelictarum", s. 369.

${ }^{21}$ Anna z Ligęzów Szembekowa - żona miecznika krakowskiego Jana Szembeka ze Słupowa (zm 1708), zob. Urzędnicy województwa krakowskiego XVI-XVIII wieku. Spisy, oprac. S. Cynarski, A. Falniowska-Gradowska, Kórnik 1990, s. 70. Należy zwrócić uwagę na fakt, że Ligęzowie nie należeli do grona typowej średniej szlachty, ale raczej do zubożałej elity szlacheckiej - członkowie rodziny jeszcze w drugiej połowie XVII w. należeli do rodzin senatorskich; na znaczeniu zyskiwała zaś rodzina Szembeków, zob. Z. Noga, Szembekowie krakowscy w XVI wieku, „Rocznik Krakowski” 71, 2005, s. 77-91.

${ }^{22}$ ANK I, CastrCracRel 133, „Oblata rerum mobilium morte Smietanczyna derelictarum", s. 471.

${ }^{23}$ Spis rzeczy po zmarłym wprowadzano do ksiąg grodzkich. Ponadto majątek po zmarłym zwykle rozdzielano - zgodnie z testamentem bądź według uznania osób uprawnionych do spadkobrania. Co naturalne, obiektem zainteresowania były zwłaszcza przedmioty najdroższe. Ich rozdzielanie - często również między osoby niespokrewnione (w tym służbę) - było wyrazem potwierdzenia statusu samego zmarłego i jego rodziny. 
nich perły uriańskie i kałakuckie ${ }^{24}$. Zdobiły one naszyjniki i zausznice, $\mathrm{z}$ powodzeniem nawlekano je też na ozdobne sznury ${ }^{25}$. W rejestrach męskich - zwłaszcza uboższej szlachty - elementem wyrażającym wysokie ambicje właściciela były pojedyncze guzy z cennych kruszców, służące do zapinania poszczególnych elementów garderoby ${ }^{26}$. W rejestrach zamożnych guzy również wzmiankowano, lecz w przeciwieństwie do inwentarzy szlachty uboższej elementy te były podzielone na całe zespoły, dopasowane wielkością i rodzajem kamienia szlachetnego do rodzaju odzieży, której miały służyć. Przykład tak przemyślanego zbioru stanowić może sporządzony w $1710 \mathrm{r}$. spis rzeczy pozostałych po kasztelanie wojnickim Janie Mikołaju Dąmbskim (zm. przed 1707) ${ }^{27}$, który miał w swoim posiadaniu osobne guzy złote, rubinowe, koralowe, srebrne i diamentowe - każde przypisane do innej części garderoby ${ }^{28}$.

Elementem jeszcze wyraźniej podkreślającym wysoki status społeczny były sygnety (zazwyczaj wykonane ze złota), często wzmiankowane w rejestrach pośmiertnych szlachty urzędniczej. Podobnie jak w przypadku innych elementów biżuterii, do nich także dołączano kamienie ozdobne, okraszając je choćby krwawnikiem czy lazurytem. Co znamienne, sygnety odnotowywano zarówno w męskich, jak i kobiecych inwentarzach. Swój „sygnecik złoty z herbem krwawnikowy, diamentami częścią kameryzowany" miała chociażby Marianna z Łodzińskich 1 voto Modrzewska, 2 voto Dobińska, wojska halicka, zmarła w 1707 r. $^{29}$

${ }^{24}$ Perły kałakuckie i uriańskie - perły pochodzące z Indii Wschodnich; zwłaszcza uriańskie były postrzegane jako szczególnie piękne, zob. E. Letkiewicz, Klejnoty w osiemnastowiecznej Polsce, Lublin 2011, s. 53.

25 Zob. ANK I, CastrCracRel 131, „Oblata regestri rerum per Trebecki porrecti”, s. 325.

${ }^{26}$ Zob. ANK I, CastrCracRel 129, „Oblata inventarii rerum mobilium morte Gnosi Trewani", s. 1295.

${ }^{27}$ Jan Mikołaj Dąmbski - miecznik inowrocławski, kasztelan wojnicki. Dwukrotnie żonaty - po raz pierwszy z kasztelanką sieradzką Katarzyną Męcińską, po jej śmierci zaś z Katarzyną Kuczkowską, zob. Urzędnicy województwa krakowskiego, s. 219; intercyza ślubna Jana Mikołaja Dąmbskiego i Katarzyny Męcińskiej spisana została w 1684 r., ale wprowadzona do krakowskich ksiąg grodzkich została dopiero w 1741 r.: ANK I, CastrCracRel 165B, „Oblata intercisa nuptialis intr. Załuski \& Dabski”, s. 127-133.

${ }^{28}$ ANK I, CastrCracRel 135, „Oblata regestri alimentorum morte M. Dąbski derelictarum", s. 1542.

29 ANK I, CastrCracRel 133, „Oblata Inventarii rerum mobilium morte ol. G. Dobinska derelicte”, s. 395. Marianna z Łodzińskich 1 voto Modrzewska, wojska halicka, jako wdowa po Krzysztofie Modrzewskim, w 1686 r. zawarła kolejny związek małżeński z również owdowiałym Krzysztofem Dobińskim (zm. 1718), porucznikiem chorągwi pancernej. Szerzej o tym małżeństwie: M. Wrede, Elekcja posłów na sejm, Proszowice 1689. W sprawie zasad głosowania na sejmikach przedsejmowych, PH 76, 1985, 2, s. 274; A. Penkała, Panieńskie ochędóstwo, s. 75. 
Odniesieniem może być też wzmiankowany wyżej rejestr zamożnego kasztelana Dąmbskiego z 1710 r., w którym podkreślono, że wśród całych zasobów wymyślnej biżuterii szlachcic pozostawił też „sygnet złoty z kamieniem szarym, na którym cztery herby nieboszczyka i na bokach sześć diamentów" ${ }^{30}$. Kilka sygnetów pozostawił też po sobie podstoli kijowski Adam Dionizy Gołuchowski ${ }^{31}$. W jego rejestrze pośmiertnym, spisanym w 1756 r., w pierwszej kolejności wymieniono jednak najważniejszy z nich - „sygnet z herbem Leliwa rżniętym w krwawniku, o sześciu diamentach po boku"32. Podobnych precjozów trudno szukać u uboższej szlachty. Należy jednak zaznaczyć, że bez względu na stan majątkowy właściciela $\mathrm{w}$ rejestrach pośmiertnych nie brak zapisków poświadczających jawne ubytki w szlachetnych kamieniach mających zdobić cenną biżuterię.

W inwentarzach męskich - oprócz sygnetów i guzów - bardzo szeroko były reprezentowane militaria. Na przykładzie odnalezionych rejestrów pośmiertnych widoczna jest też zmiana w osiemnastowiecznym szlacheckim stanie posiadania. $\mathrm{W}$ spisach $\mathrm{z}$ pierwszej połowy stulecia wzmiankowano wiele egzemplarzy broni o charakterze użytkowym i - jak zaznaczano już podczas spisywania inwentarza - noszącej wyraźne znamiona użytkowania. Od lat dwudziestych XVIII w. pojawia się coraz więcej przykładów broni paradnej, niezwykle cennej i zdobnej, stanowiącej prawdziwą dumę dla jej właściciela33. Dla uboższych przedstawicieli warstwy szlacheckiej symbol przynależności do stanu posiadającego stanowiły nawet proste rzędy końskie, okraszone kilkoma złotymi, pozłacanymi lub srebrnymi elementami. Wśród przedmiotów srebrnych powszechnie wzmiankowano szable, kańczugi i pistolety ich pokaźną reprezentację odnaleźć można nawet w tych rejestrach, które nie należały do szczególnie majętnej szlachty ${ }^{34}$. W rejestrach

30 ANK I, CastrCracRel 135, „Oblata regestri alimentorum morte M. Dąbski derelictarum", s. 1539.

${ }^{31}$ Adam Dionizy Gołuchowski - podstoli kijowski; jego pierwszą żoną była Barbara z Włodków, drugą zaś Eleonora Florentyna z Falkenhajnów. Intercyza ślubna ustalająca warunki małżeństwa pomiędzy Adamem Dionizym a Eleonorą Florentyną została zawarta w 1731 r. w Kalwarii, zob. ANK I, CastrCracRel 158, „Oblata intercisa inter Sztolcze \& Gołuchowski conscript.", s. 1219.

32 ANK I, CastrCracRel 190, „Oblata regestri rerum morte olim Gołuchowski derelictarum", s. 1682.

33 Analogiczne wnioski co do znaczenia i reprezentacji broni paradnej w inwentarzach szlachty wielkopolskiej przedstawił Jarosław Dumanowski, Świat rzeczy, s. 231-232.

${ }^{34}$ Zob. ANK I, CastrCracRel 131, „Oblata inventarii rerum mobilium morte S. Kosowski derelictarum”, s. 1658; ibidem, CastrCracRel 132, „Oblata connotationis rerum mobilium morte Modrzewski derelictarum", s. 366. 
szlachty urzędniczej - nawet tej najniższego szczebla - wykazać można pojedyncze wskazania świadczące o ambicjach i chęci dorównania zamożnym. W rejestrze wprowadzonym do ksiąg grodzkich w 1706 r., będącym spisem przedmiotów pozostałych po Kazimierzu Zagórskim, komorniku ziemskim wiślickim, pośród kilku przedmiotów o wyższej wartości wyróżnić można „parę pistoletów dzianych słoniową kością” oraz drugą w "hebanowe drewno osadzoną" 35 . W przepełnionym militariami rejestrze wpisanym do ksiąg grodzkich w 1704 r., sporządzonym po śmierci Mikołaja Mżgawy, pośród kilkunastu różnorodnych rzędów końskich, osadzonych na prostych rzemieniach i dekorowanych zwyczajnymi mosiężnymi elementami, jako jeden z najdroższych odnotowano „rząd koralowy, na którym w rzędzie jest korali czterysta, sznurki przy nim złote" ${ }^{36}$. Zamożniejsi mogli pozwolić sobie na znacznie strojniejsze, imponujące przepychem rzędy końskie ozdobione diamentami, złotymi guzami i innymi kamieniami szlachetnymi. Najdroższe z nich osadzane były dodatkowo na czerwonym safianie okalanym złotem ${ }^{37}$.

Do najpowszechniej reprezentowanych przedmiotów poświadczających określony status majątkowy ich właściciela należały elementy zastawy stołowej ${ }^{38}$. W rejestrach pośmiertnych wzmiankowano je powszechnie, najwyżej stawiając obiekty wykonane ze szlachetnych kruszców $^{39}$. Serwisy srebrne i pozłacane były jednak masowo uzupełniane przez ich tańsze odpowiedniki - naczynia wykonane z miedzi, cyny, mosiądzu - a w ostateczności - nawet z drewna. Dużą liczbę przedmiotów tańszych, użytkowanych na co dzień, można zauważyć nawet w inwentarzach majątków osób zamożnych. W rejestrach szlachty uboższej jako swoisty ozdobnik pojawiały się zapisy poświadczające posiadanie pojedynczych sztuk łyżek, czarek, konewek, lichtarzy, flasz czy miseczek wykonanych ze srebra. Układ taki dostrzec można m.in. w spisie majątku Jana Gosławskiego, wpisanym do ksiąg grodzkich w 1701 r., gdzie poza całym zestawem naczyń cynowych i mosiężnych wzmiankowane

35 ANK I, CastrCracRel 132, „Oblata regestri rerum morte olim G. Zagorski derelictarum", s. 170.

36 ANK I, CastrCracRel 131, „Oblata taxa rerum mobilium morte G. Możgawa derelictarum", s. 1852.

37 ANK I, CastrCracRel 133, „Oblata regestri rerum mobilium G. Sierakowska post mortem Mariti servien", s. 104.

${ }^{38}$ Zmiany w tym zakresie analizował w oparciu o inwentarze szlachty wielkopolskiej Jarosław Dumanowski, Świat rzeczy, s. 100-101.

39 W XVIII w. zastawa srebrna wzmiankowana była coraz powszechniej. Podobne wnioski przyniosły badania prowadzone nad inwentarzami szlachty wielkopolskiej, ibidem, s. 70-71. 
były trzy srebrne łyżki - jedyny dowód względnego luksusu, na jaki mógł pozwolić sobie ten szlachcic ${ }^{40}$. W innym inwentarzu z 1704 r. pięć srebrnych łyżeczek wyceniono prawie cztery razy drożej (na 26 tynfów) niż pierścionek złoty $\mathrm{z}$ trzema rubinkami (7 tynfów) ${ }^{41}$. W rejestrze Anny Rudzkiej, wprowadzonym do ksiąg grodzkich w tym samym roku, zdołano wykazać zaledwie kilka pierścieni i manelek wysadzanych pojedynczymi kamieniami szlachetnymi, inwentarz dopełniało jednak pięć srebrnych, niewielkich łyżeczek. Uczciwie dodano przy tym, że zaledwie trzy z nich były całe, a pozostałe dwie „zepsowane”. Przy nich ujęto też „nożenki małe bez noża” ${ }^{42}$. Inwentarz - choć skromny - akcentował jednak te elementy, które można było uznać za cokolwiek znaczące. Warto przy tym zaznaczyć, że wśród licznych wpisów zachowanych na kartach krakowskich ksiąg grodzkich odnaleziono zaledwie 16 przykładów rejestrów pośmiertnych, w których nie został umieszczony żaden przedmiot wykonany ze srebra ${ }^{43}$.

Analiza zachowanych inwentarzy pozwala wnioskować, że zamożniejsza szlachta swój status ekonomiczny podkreślała nie tylko liczbą posiadanych przedmiotów, ale także poprzez większe zróżnicowanie posiadanych elementów zastawy. Ta różnorodność widoczna jest nawet w przypadku wspomnianych wcześniej prostych łyżek stołowych.Zamożni urozmaicali swoje serwisy, zamawiając sztućce z rączkami kryształowymi, koralowymi czy jaspisowymi. Wzmiankowano też elementy wykonane z kości słoniowej, stanowiące rodzaj ekskluzywnej i prestiżowej dekoracji ${ }^{44}$. Analiza zachowanych rejestrów mienia pozwala wnioskować, że w latach dwudziestych XVIII w. coraz częściej na stołach zamożnej szlachty krakowskiej pojawiały się już nie tylko jednakowe komplety

40 ANK I, CastrCracRel 128, „Oblata inventarii rerum mobilium post olim G. Gosławski derelictarum", s. 137.

${ }^{41}$ ANK I, CastrCracRel 131, „Oblata taxa rerum mobilium morte G. Możgawa derelictarum", s. 1853-1854.

${ }^{42}$ Nożenki - zestawy mniejszych nożyków, przechowywanych razem w jednej oprawie. ANK I, CastrCracRel 131, „Oblata regestri rerum mobilium morte Rudzkiey derelictarum", s. 1473.

${ }^{43} \mathrm{~W}$ takich rejestrach wśród przedmiotów najważniejszych wykazywano mobilia, które były modne i popularne, choć zrobione z najprostszych surowców. W rejestrze Stanisława Jaworeckiego z 1722 r., świadczącym o niskiej kondycji finansowej zmarłego i pozbawionym przedmiotów niezwykle wartościowych, na początku zestawienia ujęte zostały „tabakierka drewniana jedna [--] kocioł na piwo stary łatany, [--] alembiczek trzech garcowy z rurka jedną stary zły”, ANK I, CastrCracRel 157, „G. Jaworecka manifestare et inventarium oblatare", s. 2019-2024.

${ }^{44}$ ANK I, CastrCracRel 136A, „Oblata taxa rerum mobilium morte olim Wielowieyski derelictarum", s. 753-755. 
dekorowanych srebrnych i złotych łyżek, ale nawet zestawy dedykowane wyłącznie „dla gości” czy „dla białych głów” ${ }^{45}$. Większość zachowanych wpisów wskazuje, że nawet uboższa, niepełniąca żadnych urzędów szlachta, pragnęła posiadać przynajmniej kilka przedmiotów ze srebra, najlepiej kunsztownie zdobionych. Ciekawe elementy wykazać można choćby w rejestrze pośmiertnym z 1701 r. nieznanego bliżej Adama Jacka Pawłowskiego. Oprócz licznych przykładów prostej broni wymieniono też dużą srebrną czarę o unikatowym zdobieniu, którym były „talery we dnie z Najświętszą Marią Panną"46. Po zmarłym w 1753 r. szlachcicu Pawle Rutkowskim również pozostało wiele rzeczy o stosunkowo niewielkiej wartości, prócz jednego odpowiednio wyeksponowanego cudeńka, którym była „miednica wielka srebrna pozłocista, po brzegach osoby cesarzów rzymskich wybijane”, a do niej „konewka garcowa srebrna pozłocista z uchem i wieczkiem pozłocistym, na którym stoi kupidynek" ${ }^{47}$.

Prawdziwym wyróżnikiem statusu w przypadku zastawy stołowej było dekorowanie poszczególnych elementów znakami bezpośrednio wskazującymi na osobę właściciela. W przypadku szlachty taką rolę odgrywały inicjały oraz herby. Co znamienne, wpisy poświadczające posiadanie takich przedmiotów znajdujemy zarówno wśród inwentarzy zamożnej szlachty urzędniczej, jak i znacznie uboższych przedstawicieli stanu szlacheckiego. Przykładem może być rejestr sporządzony po śmierci Stanisława Spiskiego z 1703 r., ujmujący wyłącznie proste przedmioty codziennego użytku. Pośród nich znalazła się jednak wzmianka, że właściciel miał w swoim skromnym majątku także „łyżek dwanaście, które są herbowane" ${ }^{48}$. Zmarły kilka lat później stolnik zakroczymski Jan Sierakowski ${ }^{49}$ posiadał „łyżkę blachmalową złocistą z herbem” oraz drugą łyżkę „srebrną białą, na niej herb złocisty w kratę"50. Ale nie tylko

45 ANK I, CastrCracRel 139, „Oblata rerum mobilium morte olim G. Kossecka derelictarum", s. 2217.

${ }^{46}$ ANK I, CastrCracRel 128, „Oblata rer. mobilium morte olim G. Pawłowski derelictarum", s. 3114.

47 ANK I, CastrCracRel 186, „Oblata regestri rerum mobilium olim Rutkowski derelictarum", s. 3196-3203.

48 ANK I, CastrCracRel 128, „Oblata regestri rerum mobilium morte N. Spiski olim conscripti", s. 2995.

${ }^{49}$ Jan Sierakowski - stolnik zakroczymski, starosta olszowski i mszański, żonaty z Marianną z Ruszkowskich. Ich synem był Wacław Hieronim Sierakowski, późniejszy arcybiskup lwowski, zob. E. Burda, Sierakowski Wacław Hieronim z Bogusławic h. Ogończyk (1799-1780), PSB, t. 37, Warszawa-Kraków 1996-1997, s. 307; M. Dzieduszycki, Żywot Wacława Hieronima Sierakowskiego arcybiskupa lwowskiego, Kraków 1868, s. 4.

50 ANK I, CastrCracRel 133, „Oblata regestri rerum mobilium G. Sierakowska post mortem Mariti servien", s. 105. 
łyżki ozdabiano herbem właściciela. W rejestrze majątku zmarłego Jana Trewaniego, wpisanym do ksiąg grodzkich w 1702 r., odnotowano „kubek kwartowy z herbem Leliwa złocisty" ${ }^{51}$, w spisie zaś z 1707 r. dobytku należącego do wspomnianego znacznie zamożniejszego kasztelana wojnickiego Jana Mikołaja Dąmbskiego wykazano będący oznaką prestiżu „pas na szablę z wyrysowanym herbem" 52 . Szlachta urzędnicza kazała ozdabiać herbami również rzeczy codziennego użytku. Po zmarłym w $1711 \mathrm{r}$. Stanisławie Tęgoborskim ${ }^{53}$, staroście małogoskim, pozostała miednica z nalewką z herbem i "flasze dwie graniaste z herbem" ${ }^{4}$. Nadzorując przygotowanie rejestru po śmierci kasztelana radomskiego Karola Morsztyna $^{55}$ (1748), jego żona zaś mogła potwierdzić, że do cennych mobiliów należała „miednica [--] z nalewką, z herbami męża mojego i moim”, a przy niej „czarka srebrna do płukania filiżanek” ${ }^{56}$. Popularne było też zdobienie herbami prywatnych kałamarzy. Jeden $\mathrm{z}$ takich elementów - duży „kałamarz z herbem, gwiazdą i miesiącem” - miała w swym dobytku zmarła w 1762 r. wojewodzina inflancka Helena z Potockich Morsztynowa ${ }^{57}$. Do największych elementów zdobionych w ten

${ }^{51}$ ANK I, CastrCracRel 129, „Oblata inventarii rerum mobilium morte Gnosi Trewani", s. 1295.

${ }^{52}$ ANK I, CastrCracRel 135, „Oblata regestri alimentorum morte M. Dąbski derelictarum", s. 1548.

53 Stanisław Tęgoborski - pułkownik wojsk królewskich, starosta małogoski; wraz z żoną Agatą z Wodzickich miał czwórkę dzieci. Jego córką była Marianna Teofila Tęgoborska, wydana w 1714 r. za Stanisława Dąmbskiego, zob. ANK I, CastrCracRel 141A, „Oblata intercisa G. Dąskim serviens”, s. 1743; o małżeństwie Stanisława Tęgoborskiego wspomina Herbarz polski Kaspra Niesieckiego, t. 9, wyd. J. Bobrowicz, Lipsk 1842, s. 69-70.

${ }^{54}$ ANK I, CastrCracRel 135B, „Oblata inventarii rerum olim Mci Tęgoborski Captnei Małogosten derelict", s. 2402.

${ }^{55}$ Karol z Racibroska Morsztyn - kasztelan radomski; jego żoną była Konstancja z Makowieckich, ich ślub odbył się w 1725 r.; akta Konstancji z Makowieckich Morsztynowej dotyczące zachowania praw do majątku po śmierci męża: ANK I, CastrCracRel 176, „Morsztynowa providendo manifestan.”, s. 1445.

${ }^{56}$ ANK I, CastrCracRel 178, „Oblata regestri rerum morte olim M. Morsztyn derelictarum", s. 2190- 2201.

57 ANK I, CastrCracRel 195, „Waga i taxa sreber przy kompostacyi i oddaniu sreber niżej specyfikowanych przez sukcesorów S.P. J[ej] M[oś]ci Pani Heleny z Potockich ultimo voto Morsztynowej wojewodziny inflanckiej", s. 1830. W rejestrze po zmarłej pozostało również wiele przedmiotów wykonanych ze srebra, w tym m.in.: wazy, półmiski, łyżki, lichtarze, tace, tabakierki i zegar, a także cały serwis stołowy; szerzej o postaci Heleny z Potockich Morsztynowej: J. Królikowski, Helena z Potockich Morsztynowa. Wyjątkowa kobieta staropolska i dobrodziejka Kościoła, w: Dzieje diecezji tarnowskiej, t. 3: Memoriae Ecclesiae custos. Księga pamiattkowa dedykowana ks. dr. Ryszardowi Banachowi w 70. rocznice urodzin, red. J. Jurkiewicz, A. Żurek, Tarnów 2013, s. 185-192. 
sposób, które można było znaleźć w siedzibach zamożnej szlachty urzędniczej, należały także pokaźne kredensy, wykonywane z najlepszych gatunków drewna ${ }^{58}$.

Świadectwem życia na odpowiednim poziomie i korzystania z nowinek docierających na osiemnastowieczne stoły były wzmiankowane w pośmiertnych spisach nowe elementy zastawy stołowej, przeznaczone do serwowania określonych napojów ${ }^{59}$. Były to naczynka służące do przyrządzania i picia herbaty, kawy oraz czekolady. Ich liczba, wartość, jakość wykonania, a nawet sposób, w jaki je pozyskano odzwierciedlały zamożność właściciela. W rejestrze umieszczonym w krakowskiej księdze grodzkiej w 1715 r. po raz pierwszy wzmiankowano naczynie przeznaczone wyłącznie do przygotowywania herbaty. Wpis dotyczy majątku, jaki Józefowi Gostkowskiemu pozostawiła jego małżonka - Helena z Sławeckich. Pośród różnorodnych przedmiotów wymieniona była właśnie „flaszka do herbaty blaszana"60. Od tego okresu widoczna jest tendencja do kupowania choćby pojedynczych filiżanek i łyżeczek do tego coraz bardziej popularnego napoju. Herbata przez szlachtę doceniana była stopniowo, a upodobanie do niej zwiększało się wraz z postępującą modą na produkty angielskie ${ }^{61}$.

Rosnące zapotrzebowanie na naczynia służące przygotowywaniu i serwowaniu poszczególnych napojów wynikało również ze zmieniającej się kultury konsumpcji i coraz większej skłonności do nadawania prostym czynnościom formy ceremoniału ${ }^{62}$. Zamożni zaczęli prześcigać się więc w wyborze form, kształtów i surowców, z jakich wykonywano naczynia ${ }^{63}$. Rodzaje posiadanych przedmiotów były rzecz jasna pochodną sytuacji finansowej właściciela. Zmarły w 1717 r. pułkownik królewski

58 ANK I, CastrCracRel 190, „Oblata regestri rerum morte olim Gołuchowski derelictarum", s. 1693.

${ }^{59}$ Podstawy tego zjawiska wskazywał Jarosław Dumanowski, Gorzałka, piwo i wino. Szlacheckie picie i jego materialna oprawa w XVIII wieku, w: Między barokiem a oświeceniem. Radości i troski dnia codziennego, red. S. Achremczyk, Olsztyn 2006, s. 150-151.

${ }^{60}$ ANK I, CastrCracRel 139, „Oblata regestri rerum mobilium morte G. Gostkowski derelictarum", s. 864.

${ }^{61}$ Zob. E. Martyna, Akcesoria serwisów do herbaty XVIII-XIX wiek, w: Zastawy stołowe XVI-XX w. Materiały z sesji towarzyszacej wystawie „Splendor stołu” w Muzeum Sztuki Złotniczej, Kazimierz Dolny 2006, s. 16-18; E. Wendland, Kawa, herbata i czekolada. Nowe napoje w osiemnastowiecznej Rzeczypospolitej - ich wpływ na życie codzienne, Toruń 2008.

62 Por. J. Dumanowski, Świat rzeczy, s. 111-112.

${ }^{63}$ Zob. A. Penkała, „Srebrne tabakierki, garnce gorzałczane i kotty piwne”. Obiekty kultury materialnej jako przejaw rozpowszechniania używek wśród szlachty województwa krakowskiego w pierwszej połowie XVIII wieku, w: Używki w świetle źródeł archeologicznych i historycznych, red. J. Żychlińska, A. Głowacka-Penczyńska, A. Klonder, Bydgoszcz 2016, s. 155-170. 
Franciszek Modrzewski ${ }^{64}$ zdołał włączyć w swój majątek zaledwie jeden prosty dzbanuszek do herbaty ${ }^{65}$. W dziesięć lat późniejszym rejestrze wojskiego krakowskiego Kazimierza Śmietanki ${ }^{66}$ odnotowano już „łyżeczek srebrnych małych do herbaty numero sześć, do których łyżeczek srebrny imbryczek do herbaty z wspominające rękojestką hebanową srebrny numero jeden, [--] pudełko do herbaty na cukier numero jedno"67. Zestawienie zwieńczyć może wypis z rejestru Jana Zelińskiego zmarłego w 1747 r., w którym odnotowano już kilkanaście „dzbaneczków do herbaty także farfurowych i filiżanek takichże kilkanaście"68.

Nieco później niż pierwsze wzmianki o naczyniach przeznaczonych do picia herbaty pojawiły się wpisy wspominające posiadanie przez szlachtę krakowską osobnych nakryć do kawy. Wprawdzie już w rejestrze pośmiertnym z 1706 r. po raz pierwszy odnotowano, że cześnik wiski Adam Otwinowski ${ }^{69}$ miał w swym posiadaniu proste naczynko „do kaffy"70, jednakże pewną powtarzalność podobnych zapisów dostrzec można dopiero kilkanaście lat później. W latach dwudziestych XVIII w. w inwentarzach szlacheckich coraz częściej pojawiają się młynki do kawy ${ }^{71}$, a pod koniec lat trzydziestych całe „kafeterki”, obejmujące naczynie do przyrządzenia naparu, zestawy filiżanek oraz specjalne łyżeczki ${ }^{72}$. Inne wpisy z tego okresu poświadczały, że szlachta usiłowała zdobyć środki na choćby niewielkie naczynka do przygotowania lub serwowania tego

${ }^{64}$ Franciszek Modrzewski - pułkownik wojsk królewskich, żonaty z Konstancją z Czarncy Modrzewską; jego rodzicami byli Krzysztof z Grabów Modrzewski, wojski halicki i Marianna z Chorągwic 1 voto Modrzewska, 2 voto Dobińska; dane biograficzne Modrzewskiego zostały wspomniane przy zapisywaniu przez niego posagu, umożliwiającego wstąpienie do wspólnoty zakonnej jego siostry Barbary, zob. ANK I, CastrCracRel 132, „Oblata scripti G. Modrzewska”, s. 703.

65 ANK I, CastrCracRel 141A, „Oblata rerum mobilium morte olim M. Modrzewski derelictarum", s. 218.

${ }^{66}$ Kazimierz Śmietanka z Olchowca - burgrabia krakowski, wojski krakowski, zmarł w 1727 r., zob. Urzędnicy województwa krakowskiego, s. 115.

67 ANK I, CastrCracRel 152B, „Oblata regestri rerum mobilium morte olim M. Smietanka relict.", s. 4096-4109.

${ }^{68}$ ANK I, CastrCracRel 177, „Oblata regestri rerum mobilium fatis olim Mci Zelinski derelictarum", s. 1705-1722.

${ }^{69}$ Adam Otwinowski (w źródle: Otfinowski) - cześnik wiski; jego żoną była Konstancja z Debczyna.

70 ANK I, CastrCracRel 149, „Oblata inventarii morte olim Otfinowski conscript.”, S. 2053.

${ }^{71}$ ANK I, CastrCracRel 152B, „Oblata regestri rerum mobilium morte olim M. Smietanka relict.", s. 4096-4109.

72 ANK I, CastrCracRel 162, „Oblata inventarii rerum mobilium fatis olim M. Ropp derelictarum", s. 244-251. 
napoju $\mathrm{u}^{73}$. Zbiega się to $\mathrm{w}$ czasie $\mathrm{z}$ przemianami kulturowymi i obyczajowymi, których wyrazem było m.in. sięganie po nowe rodzaje używek i chęć nadania ich spożywaniu odpowiedniej oprawy wizualnej ${ }^{74}$.

Najpóźniejszy, a zarazem jedyny w analizowanym okresie wpis, który poświadcza zakupienie naczynek przeznaczonych wyłącznie do spożywania czekolady, odnaleziony został w księdze grodzkiej z $1741 \mathrm{r}$. $\mathrm{W}$ rejestrze przedmiotów pozostałych po śmierci oboźnego wielkiego koronnego Jana Ożarowskiego wymieniona została nie pojedyncza czareczka do spożywania ekskluzywnego napoju, a cały garnitur „farfurek do kaffy i cykulady"75.

Dla osiemnastowiecznej szlachty krakowskiej wyrazem nadążania za panującą modą było też sprowadzanie przedmiotów porcelanowych czy choćby pozyskiwanie ich tańszych odpowiedników w postaci naczyń farfurowych ${ }^{76}$. Nieco rozminął się w tej kwestii z prawdą tak chętnie przywoływany przez badaczy Jędrzej Kitowicz, który w swym Opisie obyczajów podał, że dopiero „od połowy panowania Augusta III nastały talerze farfurowe dalej porcelanowe"77. Już wpisy z początku XVIII w. poświadczają posiadanie przez szlachtę pojedynczych egzemplarzy owych farfurek ${ }^{78}$. W 1704 r. w rejestrze sporządzonym po śmierci Elżbiety Gostkowskiej odnotowano, że w skład jej majątku wchodziły bliżej niesprecyzowane „cztery farfurki”79. Analizując zapisy rejestrów pośmiertnych szlachty

73 Szerzej o popularności kawy na dworach szlacheckich A. Roćko, Osiemnastowieczna przyjemność ucztowania na dworach magnackich, w: Przyjemność w kulturze epoki rozumu, red. T. Kostkiewiczowa, Warszawa 2011, s. 203.

${ }^{74}$ Por. A. Janicka, Misjonarza rzecz o kawie i nie tylko, czyli o zwyczaju picia kawy w XVIII wieku w Polsce, „Przegląd Orientalistyczny” 2013, 3-4, s. 148-151.

75 ANK I, CastrCracRel 165B, „Oblata inventarii rerum mobilium morte olim M. Ożarowski derelictarum cum iuramento”, s. 2069-2096.

${ }^{76}$ Farfur - z jęz. arabskiego, fajans; w Rzeczypospolitej terminem farfury zwyczajowo określano wyroby fajansowe, porcelanowe, a także malowane naczynia z gliny, zob. E. Kowecka, Historia manufaktur i fabryk porcelany $w$ Polsce, w: Polska porcelana, red. eadem et al., Wrocław-Warszawa-Kraków 1983, s. 10-11; szerzej o osiemnastowiecznej modzie na porcelanę, zob. A. Roćko, Porcelomania oświeconych, w: Codzienność i niecodzienność oświeconych, t. 1, s. 131.

77 J. Kitowicz, Opis obyczajów za panowania Augusta III, t. 2, oprac. R. Pollak, Wrocław 2003, s. 452.

${ }^{78}$ Zob. A. Penkała, Materia droższa od srebra. „Farfurki” $i$ „porcelanki” na szlacheckich stołach $w$ świetle inwentarzy oblatowanych $w$ krakowskich księgach grodzkich z XVIII wieku, w: Wiktuały, kuchnia, kultura jedzenia w perspektywie historycznej, red. P. Jędrzejewski, P. Magiera, K. Skrężyna, G. Szuster, Kraków 2016, s. 160-170; J. Dumanowski, Inwentarze wielmożnych, s. 263-266.

79 ANK I, CastrCracRel 131, „Oblata inventarii rerum morte Gostkowska relict.”, s. $154-158$ 
krakowskiej, można mówić o powszechnym występowaniu naczyń farfurowych zarówno w majątkach uboższej, jak i zamożnej szlachty ${ }^{80}$. Naturalne są różnice ilościowe. W spisie z 1711 r. powstałym po śmierci zubożałego szlachcica Jędrzeja Jordana z Zakliczyna ${ }^{81}$, miecznika chełmińskiego, pośród wielu zużytych, starych i mało wartych przedmiotów można było wykazać zaledwie dwie „farfurki szczerbate” i jedno „wieczko do farfurki cynowe"82, zamożniejsi natomiast gromadzili całe kufry podobnych naczyń, wśród których można wymienić talerze, misy, dzbanuszki, wanienki do płukania i filiżanki. Jeden z największych odnotowanych serwisów farfurowych należał do zmarłego w 1749 r. starosty szczerczowskiego Józefa Otwinowskiego. Szlachcic miał w swym kredensie kilkadziesiąt naczynek farfurowych, w tym czareczki i talerze „z floresami błękitnymi”

Nabywanie serwisów farfurowych było dla części szlachty namiastką pewnego luksusu, który najzamożniejszym dawało posiadanie rzeczy znacznie cenniejszych - naczyń i przedmiotów z porcelany ${ }^{84}$. Zdobione farfury miały być tańszym odpowiednikiem tego, na co wykosztowywała się ówczesna magnateria. W rejestrze pośmiertnym z 1727 r., będącym spisem majątku pozostałego po Konstancji Morskiej, pośród opisu kredensu znaleźć można ciekawy zabieg - odnotowano wprawdzie kilka „porcyjanek”, dodając przy tym, że są to owe „porcyjanki farfurowe gdańskie" 85 . Pierwszy duży serwis porcelanowy został wykazany w spisie sporządzonym w 1741 r. po śmierci oboźnego wielkiego koronnego Jerzego Ożarowskiego. Miał on w swym posiadaniu nie tylko pełen „serwis saski”, ale także osobne „porcelany na kominku" 86 . W badaniach nad majątkiem ruchomym szlachty wielkopolskiej obecność porcelany wykazana została w inwentarzach z drugiej połowy XVIII w., przeważnie z końca

${ }^{80} \mathrm{Na}$ ich niższą cenę przełożył się fakt, że wraz z rosnącą popularnością tego rodzaju naczyń ośrodki do produkcji surowca koniecznego do wytwarzania owych farfur powstawały w dobrach należących do przedstawicieli magnaterii i zamożnej szlachty. Zob. Historia kultury materialnej, s. 176.

${ }^{81}$ Jędrzej Jordan z Zakliczyna - miecznik chełmiński; jego małżonką była Salomea ze Stradomia 1 voto Januszowska.

${ }^{82}$ ANK I, CastrCracRel 136B, „Oblata rerum mobilium morte post fata Generosi Jordan derelictarum”, s. 2448-2450.

83 ANK I, CastrCracRel 179, „Oblata rerum mobilium morte post fata M. Otfinowski captnei Szczerczoviensis derelictarum", s. 930-939.

${ }^{84}$ E. Wendland, op. cit.

${ }^{85}$ ANK I, CastrCracRel 151B, „Oblata regestri morte olim Morska derelictarum”, s. 3551 .

${ }^{86}$ ANK I, CastrCracRel 165B, „Oblata inventarii rerum mobilium morte olim M. Ożarowski derelictarum cum iuramento”, s. 2069-2096 
omawianego okresu ${ }^{87}$. W przypadku szlachty krakowskiej powtarzalność wpisów, w których są wzmiankowane pojedyncze przedmioty porcelanowe, również można zaobserwować dopiero wśród rejestrów pośmiertnych z lat pięćdziesiątych ${ }^{88}$. Najbardziej imponujący serwis porcelanowy wzmiankowany na kartach krakowskich ksiąg grodzkich należał do zmarłego w 1763 r. kasztelana wojnickiego Adama Jordana z Zakliczyna ${ }^{89}$. Kasztelan miał w swym majątku kilkadziesiąt naczyń porcelanowych, w tym naczynia zdobione kogutami, błękitnymi kwiatami, różami, fałdowanymi brzegami czy „floresami i domkami w środku malowanymi”"

Oprócz licznie reprezentowanej zastawy stołowej, także na przykładzie innych przedmiotów codziennego użytku można wykazać zmieniające się upodobania i dążenie do podkreślenia szlacheckiego statusu za pomocą gromadzonych rzeczy. Do powszechnie wzmiankowanych elementów należały srebrne i pozłacane miednice z nalewkami, służące do obmywania ciała. W większości inwentarzy wymieniane były przedmioty bardzo proste, o których wartości świadczyć miał wyłącznie kruszec, z jakiego zostały wykonane. Jakości dodawało im co najwyżej wyzłacanie brzegów ${ }^{91}$. Dążenie do wyróżnienia się spośród uboższej i średnio zamożnej szlachty widoczne było w rodzaju zamawianych przedmiotów i kunszcie ich wykonania. W rozległym majątku kasztelana wojnickiego Jana Mikołaja Dąmbskiego zbyt mało znaczyły proste naczynia srebrne zamiast nich na potrzeby szlachcica sprowadzono do ozdobienia miednicy „gąsiory dwa pstro złociste z łańcuszkami”, a oprócz tego posiadał on „kałamarz oprawny we srebro hebanem nasadzany, na wierzchu osóbka srebrna"92.

87 Zob. J. Dumanowski, Świat rzeczy, s. 105.

88 ANK I, CastrCracRel 184, „Oblata regestri rerum mobilium per Magnificum Lubieniecki conscript.”, s. 709-712; ibidem, CastrCracRel 184, „Oblata regestri rerum post fatis Zelenskiego derelictarum", s. 1290.

${ }^{89}$ Adam Jordan z Zakliczyna - generał lejtnant wojsk koronnych, kasztelan wojnicki, kawaler Orderu Orła Białego, zob. T. Ciesielski, Generałowie wojska koronnego w latach 1717-1763, w: Organizacja armii w nowożytnej Europie. Struktura - urzędy - prawo - finanse, red. K. Łopatecki, Zabrze 2011, s. 465. Pozycja majątkowa Adama Jordana była pochodną kilku czynników. Jego ojciec, Michał Stefan Jordan, był wojewodą bracławskim i właścicielem ogromnego majątku. Dzięki korzystnemu zapleczu finansowemu Adam Jordan mógł zawrzeć małżeństwo z Marianną, córką Jerzego Ignacego Lubomirskiego (zm. 1753) oraz pozyskać atrakcyjne stanowiska urzędnicze.

90 ANK I, CastrCracRel 197, „Regestr mobilii jako to klejnotów [--]”, b.pag.

91 ANK I, CastrCracRel 129, „Oblata inventarii rerum mobilium morte Gnosi Trewani", s. 1295.

92 ANK I, CastrCracRel 135, „Oblata regestri alimentorum morte M. Dąbski derelictarum", s. 1547. 
W XVIII w. wiele ze swego dawnego prestiżu straciły zegary. Nawet uboższy szlachcic mógł pozwolić sobie na prosty zegar tarczowy czy jeden z zegarów mosiężnych ${ }^{93}$. Ich posiadanie wzmiankowane było coraz częściej - zamożni inwestowali więc w precjoza z najcenniejszego kruszcu, bogato zdobione i kunsztownie wykonane. $\mathrm{W}$ rejestrze wprowadzonym do ksiąg w 1706 r., oddającym stan majątku po śmierci cześnika wiskiego Adama Otwinowskiego wymienione były już trzy zegary - mały pektoralik, duży mosiężny zegar i trzeci - najciekawszy — „zegarek w ramkach drewnianych z listewkami w srebro oprawnymi"94. Najzamożniejsi $\mathrm{w}$ połowie stulecia inwestowali już w precyzyjnie wykonywane zegary „godziny bijące z cyberblatem”, wykonane z drewna i cennych kruszców ${ }^{95}$.

Ambicje i chęć posiadania przedmiotów unikatowych, odpowiadających szlacheckiemu statusowi, znajdowały odzwierciedlenie także w sferze religijnej. W większości rejestrów znaleźć można jedynie proste zapiski poświadczające posiadanie „koralików do modlenia”, jednego lub kilku egzemplarzy Biblii czy niewielkich obrazów przedstawiających popularnych świętych. Jednakże nawet tutaj można zauważyć dążenia do posiadania rzeczy cenniejszych. W rejestrach pośmiertnych znaleźć można wzmianki o przechowywanych na prywatny użytek złotych kielichach i innych bogato zdobionych naczyniach liturgicznych wykonanych z najcenniejszych kruszców. Inwentarze poświadczają też inwestowanie w różnej wielkości krzyże, wykonane z cennych materiałów i kunsztownie zdobione. W rejestrze z $1702 \mathrm{r}$. spisanym po śmierci Jana Trewaniego odnotowano „krzyż ze srebrnymi okowkami, na końcach osóbki dwie z kości rżnięte w pudełkach" ${ }^{96}$. Wykosztowywano się też na sprowadzanie strojnych relikwiarzy, odpowiednio kunsztownie wykonanych ${ }^{97}$. We wskazanym rejestrze z $1702 \mathrm{r}$. wzmiankowano relikwiarz z wieloma elementami wykonanymi z kości słoniowej. Na cenny egzemplarz składał się „krzyż czarny z figurą słoniową w ołtarzyku małym z relikwiami"98. Popularność tych elementów widoczna jest w rejestrach średniej i zamożniejszej

93 ANK I, CastrCracRel 131, „Oblata inventarii rerum mobilium morte S. Kosowski derelictarum", s. 1659.

94 ANK I, CastrCracRel 132, „Oblata inventarii morte oli. Otfinowski conscript.”, s. 1606.

95 ANK I, CastrCracRel 197, „Regestr mobilii jako to klejnotów [--]”, b.pag.

96 ANK I, CastrCracRel 129, „Oblata inventarii rerum mobilium morte Gnosi Trewani", s. 1295.

${ }^{97}$ Pięć relikwiarzy zostawiła po swej śmierci w 1710 r. Eufrozyna z Kieszkowskich Ściborowa, ANK I, CastrCracRel 135, „Oblata regestri post G. F. Kieszkowski por recti”, s. 1481.

${ }^{8}$ ANK I, CastrCracRel 129, „Oblata inventarii rerum mobilium morte Gnosi Trewani", s. 1295. 
szlachty w całym analizowanym okresie. Jeszcze w inwentarzu spisanym w 1756 r., ujawniającym stan posiadania podstolego kijowskiego Adama Dionizego Gołuchowskiego, kolekcję obrazów „wyrażających Pana Jezusa i Najświętszą Marię Pannę” uzupełniały trzy „relikwiarze za szkłem”99.

Przejawem luksusu i prestiżu było też posiadanie kolekcji obrazów, dekorujących przestrzeń mieszkalną. Większość wzmianek w inwentarzach pośmiertnych szlachty krakowskiej stanowią proste wskazania o posiadaniu jednego lub kilku obrazów o tematyce religijnej. Tym ciekawsze są więc wszelkie zapiski wskazujące na znacznie wyższy standard życia i wykraczanie poza średni poziom zamożności. Szczególnie szlachta urzędnicza wykorzystywała fakt posiadania kolekcji obrazów o różnej tematyce do zaakcentowania swej pozycji. W rejestrach przedstawicieli zamożniejszej szlachty pojawiały się wzmianki o posiadaniu kolekcji, mających cieszyć oko i oddawać dobry gust właściciela. W tym celu zamawiano obrazy ukazujące martwą naturę, scenki rodzajowe i przedstawienia alegoryczne. Najwyższym wyrazem prestiżu było posiadanie portretów, przedstawiających zarówno samego ich właściciela, jak i najbliższych krewnych. Jedną z ciekawszych kolekcji obrazów miał starosta małogoski Stanisław Tęgoborski, zmarły w $1711 \mathrm{r}$. W rozległym spisie mobiliów pozostałych po jego śmierci znajdowały się portrety króla Michała i króla Jana, włoskie sceny rodzajowe: „dwie osoby i dwóch kupidynów, obraz włoski na którym dwie osoby i wół, obraz okrągły na którym osoba trzyma ptaszka i troje dzieci bawiące się"100. Galerię uzupełniały obrazy nieboszczki żony starosty oraz „nieboszczyka pana kasztelana żarnowskiego, ojca Jegomości"101. Kolekcję kilkunastu portretów ujęto też w rejestrze spisanym po śmierci Zygmunta Łubińskiego w 1754 r. Wśród nich dodatkowo wyróżniono serię wizerunków generalskich i różnych obrazów malowanych na płótnie ${ }^{102}$. Jedną z najbardziej imponujących kolekcji, ujętych na kartach krakowskich ksiąg grodzkich, były zbiory zgromadzone przez Adama Jordana z Zakliczyna ${ }^{103}$. Zmarły w 1763 r. kasztelan miał w swej kolekcji m.in.: „portret króla J[ego] M[oś] ci pruskiego", a także podobizny osób z najbliższego otoczenia jego i żony,

99 ANK I, CastrCracRel 190, „Oblata regestri rerum morte olim Gołuchowski derelictarum", s. 1693.

100 ANK I, CastrCracRel 135B, „Oblata inventarii rerum olim Mci Tęgoborski Captnei Małogosten derelict", s. 2409.

101 Ibidem.

102 ANK I, CastrCracRel 187, „Oblata inventarii rerum mobilium morte olim Illustris Magnifici Łubinski derelictarum iuramento corporali cum probatarum hoc loci ad acticandum porrectarum", s. 1756.

103 ANK I, CastrCracRel 197, „Regestr mobilii jako to klejnotów [--]”, b.pag. 
jak dwa „portrety Książąt IchM[oś]ć Lubomirskich”, „portret wielki stary księcia Stanisława Lubomirskiego” czy „portret księdza J[ego] M[oś]ci biskupa krakowskiego Załuskiego"104.

Dodatkowym elementem niezwykle rzadko wzmiankowanym w szlacheckich inwentarzach były przedmioty służące rozrywce. Wśród nich wyróżniały się warcabnice, odnotowane w kilku rejestrach pośmiertnych. Najczęściej inwentarze poświadczały posiadanie przez zmarłego prostego stołu z warcabnicą, służącego do codziennej rozrywki. Należy jednak zaznaczyć, że w osiemnastowiecznych spisach rzeczy pozostałych po przedstawicielach szlachty urzędniczej warcabnice można odnaleźć także wśród grup przedmiotów odpowiednio droższych, ze stosownym opisem szerzej charakteryzującym zachowany obiekt. $W$ rejestrze pośmiertnym z 1707 r. Jana Sierakowskiego, stolnika zakroczymskiego, wzmiankowana była „warcabnica hebanowa kością słoniową sadzona z warcabami kościanymi białymi i czarnymi, także z kostkami"105. W znacznie późniejszym rejestrze z 1761 r., spisanym po śmierci kasztelana połanieckiego Stanisława z Brzezia Lanckorońskiego, odnotowano już kilka warcabnic, w tym kamienną i drewnianą ${ }^{106}$. Pojedyncze spisy zawierały też wzmianki poświadczające posiadanie przez zamożniejszą część szlachty kosztownych stolików karcianych. Tego typu obiekt wymieniony był m.in. w rejestrze spisanym po śmierci miecznika czerskiego Stanisława Dębskiego. W sporządzonym w 1755 r. wykazie ujęty został „stolik zielonym suknem obity, do kart"107. Za pewien ewenement uznać można skórzane kręgle pokojowe, wzmiankowane zaledwie w kilku rejestrach zamożnej szlachty urzędniczej. Wspomniany wcześniej Adam Jędrzej z Zakliczyna, kasztelan wojnicki, miał u siebie m.in. „kręgle małe do grania stołowe”, zestawione wśród przedmiotów służących rozrywce $\mathrm{z}$ „wiatraczkiem do strzelania” i „klatką drucianą na kanarka” ${ }^{108}$. Największą atrakcję stanowić jednak musiał „bilar dobry suknem zielonym obity, nakrycie na tym z płótna woskowanego" do tego kilka "gałek do bilaru słoniowych" dwa „kije do tegoż bilaru” i wieńcząca komplet „tablica z wynikami”109.

104 Portret przedstawiał zapewne Andrzeja Stanisława Kostkę Załuskiego (zm. 1758), ANK I, CastrCracRel 197, „Regestr mobilii jako to klejnotów [--]”, b.pag.

105 ANK I, CastrCracRel 133, „Oblata regestri rerum mobilium G. Sierakowska post mortem Mariti servien", s. 106.

106 ANK I, CastrCracRel 194, „Oblata regestri rerum mobilium fatis olim Lanckoroński derelictarum", s. 2181.

107 ANK I, CastrCracRel 187, „Oblata regestri rerum mobilium morte olim Magnifici Dębski derelictarum M. Paczkowa conscript. et iuramentum comprobari”, s. 2890.

108 ANK I, CastrCracRel 197, „Regestr mobilii jako to klejnotów [--]”, b.pag.

109 Ibidem. 
Warto nadmienić, że dążenie do posiadania choćby pojedynczych cennych i reprezentacyjnych przedmiotów powodowało, że przedstawiciele uboższej szlachty pozbywali się rzeczy niemodnych i nadpsutych, zlecając ich przetopienie i wykonanie czegoś, co choć trochę mogłoby przybliżyć styl życia możnych. W 1719 r. żona burgrabiego krakowskiego Mikołaja Łodzińskiego, inwentaryzując majątek po zmarłym mężu przyznała, że „łyżek srebrnych staroświeckich sześć [--] z inszym srebrem to jest konewką srebrną i z trzech szabel srebrem zdjętym [oddała - A.P.-J.] na zrobienie naczynia do kaffy. W co i moja konewka wchodzi upominkowa i puchar srebrny"110. Wdowa po Albercie Księskim zdecydowała się przetopić część należących do męża militariów, w tym ciężki „obuch staroświecki w srebro oprawny". Z pozyskanego w ten sposób kruszcu nakazała stworzyć dla męża ostatnią namiastkę „luksusu”. Jak dopisała w zachowanym rejestrze pośmiertnym, to wszystko „dałam przerobić na serce srebrne, na tę pamiątkę, że wnętrzności jego leżą we Gdowie"111.

Analiza szlacheckich rejestrów pośmiertnych z osiemnastowiecznych krakowskich ksiąg grodzkich, będących podstawowym przedmiotem niniejszych studiów, pozwala dostrzec, w jaki sposób poprzez majątek ruchomy manifestowano prestiż w kręgach zamożnej szlachty oraz na ile średnia i uboższa szlachta - której inwentarze dominują w analizowanym materialne źródłowym - wzorowała się i inspirowała stylem życia najbogatszych. W wielu wypadkach nie pozwalały na to warunki finansowe, a obecność kilku przedmiotów o wyższej wartości stanowiła formę pokoleniowej lokaty kapitału. Należy bowiem podkreślić, że dla części przedstawicieli stanu szlacheckiego zgromadzenie przedmiotów o wysokiej wartości było możliwe wyłącznie poprzez ich dziedziczenie, a nie nabywanie - trudno więc mówić o podążaniu za gustem epoki bądź wzorowaniu się na działaniach osób zamożnych. Wypisy z inwentarzy pośmiertnych poświadczają za to skalę popularności określonych przedmiotów. Zestawienie dużej liczby rejestrów pozwala uchwycić proces powszechnienia określonych towarów, pierwotnie zastrzeżonych wyłącznie dla warstwy najbogatszej. Wraz z upływem lat i zwiększoną dostępnością na rynku lokalnym tych przedmiotów, które zwyczajowo stanowiły wyróżnik warstwy najbogatszej, zamożni inwestowali raczej w przedmioty unikatowe pod względem precyzji wykonania, użytego kruszcu, gustu artystycznego. Wykazać można wiele elementów, które pozwalają wnioskować na temat

110 ANK I, CastrCracRel 142, „Oblata regestri rerum mobilium et immobilium morte Generosi Łodzinski derelictarum", s. 929.

111 ANK I, CastrCracRel 135B, „Oblata regestri rerum mobilium morte olim Alberti Xsięski derelictare", s. 3837. 
poziomu zamożności ich właściciela. Do przedmiotów prestiżowych, niewykazanych w niniejszym zestawieniu, a uchwytnych na kartach krakowskich ksiąg grodzkich zaliczyć można różnorodne instrumenty muzyczne, precyzyjnie wykonane sepety, szafy i skrzynie, nierzadko sprowadzane z odległych regionów świata, czy choćby zasoby szlacheckich bibliotek, skrupulatnie wykazywanych i odpowiednio wycenianych. Zgromadzenie w swym majątku wielu rzeczy srebrnych i złotych, kolekcji biżuterii wysadzanej kamieniami szlachetnymi, kunsztownie zdobionej zastawy stołowej czy wreszcie eleganckich przedmiotów służących codziennej rozrywce było wyrazem szlacheckich ambicji finansowych i społecznych. Pośmiertne inwentarze mienia konstruowano więc w taki sposób, aby uwypuklić w nich wszelkie przykłady mobiliów mogących przedstawiać pewną wartość, nawet jeżeli możliwości finansowe kończyły się na pozyskaniu pojedynczych srebrnych bibelotów. Zachowane wzmianki dotyczące przedmiotów kultury materialnej są doskonałym przykładem dążeń i ambicji, skłonności do naśladowania bogatszych od siebie, ale równych urodzeniem przedstawicieli stanu szlacheckiego.

\section{Streszczenie}

Przedmioty ujmowane w inwentarzach mobiliów należących do zmarłych osób ze stanu szlacheckiego stanowią wartościowe źródło, ujawniające tendencje do pozyskiwania i gromadzenia określonych dóbr, nie tyle ze względów praktycznych, co ambicjonalnych. $\mathrm{W}$ artykule podjęto zadanie ustalenia, czy posiadanie choćby kilku drobnych przedmiotów wykonanych z cennych kruszców w XVIII w. mogło być traktowane jako synonim luksusu, osiągnięcia określonej pozycji materialnej, a nawet pewien wyróżnik pozycji społecznej przedstawicieli osiemnastowiecznej szlachty. Podstawę źródłową badań stanowi obszerny materiał archiwalny, liczący 306 inwentarzy pośmiertnych z krakowskich ksiąg grodzkich z lat 1701-1763. Na podstawie zachowanego materiału źródłowego przenalizowano kilka grup przedmiotów wzmiankowanych w szlacheckich inwentarzach pośmiertnych, które mogły wskazywać na status majątkowy zmarłego. Zachowane zapisy pozwalają też na ujawnienie zabiegów, mających na celu pozyskanie choćby pojedynczych cennych przedmiotów - nawet w przypadku niższego statusu ekonomicznego właściciela. Wśród przeanalizowanych znalazły się biżuteria, broń, zastawa stołowa czy rzeczy służące rozrywce. Wypisy z inwentarzy pośmiertnych umożliwiają ocenę skali ich popularności. Zestawienie dużej liczby spisów ma zaś na celu uchwycenie procesu powszechnienia określonych towarów, pierwotnie zastrzeżonych wyłącznie dla warstwy najbogatszej. Zachowany materiał źródłowy pozwala wnioskować, że wraz z upływem lat i zwiększoną dostępnością na rynku lokalnym tych przedmiotów, które zwyczajowo stanowiły wyróżnik warstwy najbogatszej, zamożni chętniej inwestowali w przedmioty unikatowe pod względem precyzji wykonania, użytego kruszcu czy gustu artystycznego. 


\section{The Silver Spoon Myth? Prestigious Objects in the Noble Property Inventories from the Borough Records of the Palatinate of Cracow in the Saxon Period}

Registers of movable property belonging to deceased noblemen present a valuable source, revealing the tendencies to acquire and collect certain goods for ambitious rather than practical reasons. The article attempts to determine whether the possession of only a few small such objects made of valuable metal ores could be regarded in the eighteenth century as a synonym of luxury, achieving a specific financial position, or even a certain characteristic of the social standing of noblemen at that time. The research is based on extensive archival material composed of 306 post-mortem inventories from the Cracow borough registers compiled between 1701 and 1763. On the basis of these inventories, several groups of objects were analysed that could indicate the financial status of the deceased. The preserved records make it possible for us to reveal ways in which individual objects could have been acquired - even in the case of the owner's lower financial status. Among the analysed goods, there are jewellery, weapons, tableware, or items for entertainment. Excerpts from the posthumous inventories allow us to estimate the scale of their popularity, while a comparison of a large number of inventories serves to provide a comprehensive grasp of the process of becoming common of specific goods, originally reserved for the richest class. The preserved sources justify the conclusion that, with the lapse of time and increased local supply of objects which traditionally distinguished the richest, wealthy noblemen were more eager to invest into items unique in terms of high precision of their manufacturing, valuable material they were made of, or artistic taste.

\section{Bibliografia}

Białkowski Leon, 0 znaczeniu ksiagg grodzkich dla historii obyczajów i kultury materialnej, w: Pamiętnik IV Powszechnego Zjazdu Historyków Polskich w Poznaniu 6-8 XII 1925, t. 1: Referaty, PTH, Lwów 1925, s. 1-7.

Bieńkowska Barbara, Inwentarze księgozbiorów prywatnych jako źródła do badań nad dziejami czytelnictwa, „Studia o Książce” 18, 1989, s. 65-76.

Burda Elżbieta, Sierakowski Wacław Hieronim z Bogusławic h. Ogończyk (1799-1780), PSB, t. 37, Warszawa-Kraków 1996-1997.

Chodyński Antoni Romuald, Obyczajowość polska w świetle inwentarzy Czapskich herbu Leliwa z pierwszej połowy XVIII wieku, „Kwartalnik Historii Kultury Materialnej” $51,2003,2$, s. $277-290$.

Ciara Stefan, Senatorowie i dygnitarze koronni w drugiej połowie XVII wieku, Ossolineum, Wrocław 1990.

Ciesielski Tomasz, Generałowie wojska koronnego w latach 1717-1763, w: Organizacja armii w nowożytnej Europie. Struktura - urzędy - prawo - finanse, red. Karol Łopatecki, Inforteditions, Zabrze 2011, s. 445-476. 
Cui contingit nasci, restat mori. Wybór testamentów staropolskich z województwa sandomierskiego, oprac. Mariusz Lubczyński, Jacek Pielas, Henryk Suchojad, Semper, Warszawa 2005.

Domański Henryk, Stratyfikacyjne funkcje prestizu , „Przegląd Socjologiczny” 68, 2019, 2, s. 187-208.

Dumanowski Jarosław, Gorzałka, piwo i wino. Szlacheckie picie i jego materialna oprawa w XVIII wieku, w: Między barokiem a oświeceniem. Radości i troski dnia codziennego, red. Stanisław Achremczyk, Ośrodek Badań Naukowych im. Wojciecha Kętrzyńskiego, Olsztyn 2006, s. 148-154.

Dumanowski Jarosław, Inwentarze wielmożnych i urodzonych. Konsumpcja szlachty wielkopolskiej w XVIII w., „Kwartalnik Historii Kultury Materialnej” 51, 2003, 2, s. 261-276.

Dumanowski Jarosław, Przepych i tezauryzacja. Bizuteria w inwentarzach ruchomości szlachty wielkopolskiej w XVIII wieku, w: Biżuteria w Polsce. Treści, teksty, przesłania, red. Katarzyna Kuczwajd, Toruńska Oficyna Wydawnicza, Toruń 2005, s. 51-60.

Dumanowski Jarosław, Świat rzeczy szlachty wielkopolskiej w XVIII wieku, Wydawnictwo UMK, Toruń 2006.

Dzieduszycki Maurycy, Żywot Wacława Hieronima Sierakowskiego arcybiskupa lwowskiego, Drukarnia „Czasu” W. Kirchmayera, Kraków 1868.

Główka Dariusz, Klonder Andrzej, Inwentarze mienia w badaniach kultury Europy od średniowiecza po nowożytność, „Kwartalnik Historii Kultury Materialnej” 51, 2003, 2, s. 157-176.

Góralski Zbigniew, Urzędy i godności w dawnej Polsce, LSW, Warszawa 1984.

Historia kultury materialnej Polski w zarysie, t. 4: Od połowy XVII do końca XVIII wieku, red. Zofia Kamieńska, Bohdan Baranowski, Ossolineum, Wrocław 1978.

Janicka Anna, Misjonarza rzecz o kawie i nie tylko, czyli o zwyczaju picia kawy w XVIII wieku w Polsce, „Przegląd Orientalistyczny” 2013, 3-4, s. 148-151.

Kicińska Urszula, Splendory domowe w staropolskich inwentarzach ruchomości, „Kwartalnik Historii Kultury Materialnej" 65, 2017, 4, s. 461-470.

Kitowicz Jędrzej, Opis obyczajów za panowania Augusta III, t. 2, oprac. Roman Pollak, Ossolineum, Wrocław 2003.

Kowecka Elżbieta, Historia manufaktur i fabryk porcelany w Polsce, w: Polska porcelana, red. Elżbieta Kowecka et al., Ossolineum, Wrocław-Warszawa-Kraków 1983.

Królikowski Janusz, Helena z Potockich Morsztynowa. Wyjątkowa kobieta staropolska i dobrodziejka Kościoła, w: Dzieje diecezji tarnowskiej, t. 3: Memoriae Ecclesiae custos. Księga pamiatkowa dedykowana ks. dr. Ryszardowi Banachowi w 70. rocznicę urodzin, red. Jerzy Jurkiewicz, Antoni Żurek, Biblos, Tarnów 2013, s. 185-192.

Letkiewicz Ewa, Klejnoty w osiemnastowiecznej Polsce, Wydawnictwo UMCS, Lublin 2011.

Martyna Ewa, Akcesoria serwisów do herbaty XVIII-XIX wiek, w: Zastawy stołowe XVI-XX w. Materiały z sesji towarzyszacej wystawie „Splendor stołu” w Muzeum Sztuki Złotniczej, Kazimierz Dolny 2006, s. 16-22, https://docplayer.pl/ 5535539-Xvi-Xx-materialy-z-sesji-towarzyszacej-wystawie-splendor-stoluw-muzeum-sztuki-zlotniczej-kazimierz-dolny-26-27-pazdziernika-2006.html.

Mohrmann Ruth Elisabeth, Pośmiertne inwentarze mienia - krytyka źródła, problemy badawcze, „Kwartalnik Historii Kultury Materialnej” 53, 2005, 2, s. 137-146. 
Herbarz polski Kaspra Niesieckiego, t. 9, wyd. Jan Bobrowicz, Breitkopf i Hærtel, Lipsk 1842.

Noga Zdzisław, Szembekowie krakowscy w XVI wieku, „Rocznik Krakowski” 71, 2005, s. 77-91.

Penkała Anna, „Srebrne tabakierki, garnce gorzałczane i kotty piwne”. Obiekty kultury materialnej jako przejaw rozpowszechniania używek wśród szlachty województwa krakowskiego w pierwszej połowie XVIII wieku, w: Używki w świetle źródeł archeologicznych i historycznych, red. Justyna Żychlińska, Anetta Głowacka-Penczyńska, Andrzej Klonder, Wydawnictwo Uniwersytetu Kazimierza Wielkiego, Bydgoszcz 2016, s. 155-170.

Penkała Anna, Panieńskie ochędóstwo. Kwestie posagowe $i$ wienne $w$ małżeństwach szlachty województwa krakowskiego w czasach saskich, Libron, Kraków 2016.

Penkała Anna, Materia droższa od srebra. „Farfurki” i „porcelanki” na szlacheckich stołach $w$ świetle inwentarzy oblatowanych w krakowskich księgach grodzkich z XVIII wieku, w: Wiktuały, kuchnia, kultura jedzenia w perspektywie historycznej, red. Przemysław Jędrzejewski, Piotr Magiera, Klaudia Skrężyna, Gabriel Szuster, Avalon, Kraków 2016, s. 160-170.

Pielas Jacek, Podziały majątkowe szlachty koronnej w XVII wieku, Wydawnictwo Uniwersytetu Jana Kochanowskiego, Kielce 2013.

Popiołek Bożena, Manelek dwie i pereł sznurów cztery. 0 szlacheckich inwentarzach posagowych i pośmiertnych z XVIII wieku, „Annales Academiae Paedagogicae Cracoviensis. Studia Historica" 4, 2005, s. 166-173.

Popiołek Bożena, Woli mojej ostatniej testament ten... Testamenty staropolskie jako źródło do historii mentalności XVII i XVIII wieku, Wydawnictwo Naukowe Uniwersytetu Pedagogicznego, Kraków 2009.

Popiołek Bożena, Z kraju i ze świata. Krakowskie nowiny rękopiśmienne z 1729 r. jako źródło do historii mentalności społeczeństwa czasów saskich, „Rocznik Historii Prasy Polskiej" 15, 2012, 1 (29), s. 23-39.

Pośpiech Andrzej, Majątek osobisty szlachcica w świetle wielkopolskich pośmiertnych inwentarzy ruchomości z XVII wieku, „Kwartalnik Historii Kultury Materialnej” 29, 1981, 4, s. 463-482.

Pośpiech Andrzej, Pułapka oczywistości. Pośmiertne spisy ruchomości szlachty wielkopolskiej z XVII wieku, IAiE PAN, Warszawa 1992.

Pośpiech Andrzej, Srebrna łyżka - probierz szlacheckiej zamożności? (Przykład Wielkopolski XVII wieku), w: Nędza i dostatek na ziemiach polskich od średniowiecza po XX wiek, red. Janusz Sztetyłło, Semper, Warszawa 1992, s. 151-162.

Roćko Agata, Osiemnastowieczna przyjemność ucztowania na dworach magnackich, w: Przyjemność w kulturze epoki rozumu, red. Teresa Kostkiewiczowa, DiG, Warszawa 2011. Roćko Agata, Porcelomania oświeconych, w: Codzienność i niecodzienność oświeconych, t. 1: Przyjemności, pasje i upodobania, red. Bożena Mazurkowa, Wydawnictwo UŚ, Katowice 2013, s. 127-145.

Roćko Agata, Sarmacki świat wartości materialnych w XVIII wieku. Zarys problematyki, w: Codzienność i niecodzienność oświeconych, t. 1: Przyjemności, pasje i upodobania, red. Bożena Mazurkowa, Wydawnictwo UŚ, Katowice 2013, s. 11-22.

Testamenty szlacheckie z ksiag grodzkich wielkopolskich 1657-1680, wyd. Paweł Klint, Wydawnictwo Historyczne, Wrocław 2011 (Źródła Dziejowe, t. 28). 
Testamenty szlacheckie z ksiag grodzkich wielkopolskich z lat 1631-1655, wyd. Paweł Klint, Wydawnictwo Historyczne, Poznań-Wrocław 2008 (Źródła Dziejowe, t. 27).

Testamenty szlachty krakowskiej XVII-XVIII w. Wybór tekstów źródłowych z lat 1650-1799, wyd. Alicja Falniowska-Gradowska, PAU, Kraków 1997.

Toczyńska Magdalena Bożena, o biżuterii oświeconych uwag kilka, w: Codzienność i niecodzienność oświeconych, t. 1: Przyjemności, pasje i upodobania, red. Bożena Mazurkowa, Wydawnictwo UŚ, Katowice 2013, s. 111-126.

Turnau Irena, Słownik ubiorów. Tkaniny, wyroby pozatkackie, skóry, broń i klejnoty oraz barwy znane w Polsce od średniowiecza do początku XIX w., Semper, Warszawa 1999.

Urzędnicy województwa krakowskiego XVI-XVIII wieku. Spisy, oprac. Stanisław Cynarski, Alicja Falniowska-Gradowska, Biblioteka Kórnicka, Kórnik 1990.

Wendland Ewa, Kawa, herbata i czekolada. Nowe napoje w osiemnastowiecznej Rzeczypospolitej - ich wpływ na życie codzienne, Dom Wydawniczy Duet, Toruń 2008.

Wrede Marek, Elekcja posłów na sejm, Proszowice 1689. W sprawie zasad głosowania na sejmikach przedsejmowych, „Przegląd Historyczny” 76, 1985, 2, s. 269-289.

Wyczański Andrzej, Studia nad konsumpcja żywności w Polsce w XVI i pierwszej połowie XVII w., PWN, Warszawa 1969.

Zielińska Teresa, Kosztowności jako składnik wyposażenia kobiet w XVII i XVIII wieku, w: Miasto - region - społeczeństwo. Studia ofiarowane Profesorowi Andrzejowi Wyrobiszowi w sześćdziesiąta rocznice Jego urodzin, red. Ewa Dubas-Urwanowicz, Jerzy Urwanowicz, Dział Wydawnictw FUW, Białystok 1992.

Zielińska Teresa, Rody urzędami zaszczycone. Próba sondażu, w: Społeczeństwo staropolskie, Studia i szkice, t. 2, red. Andrzej Wyczański, PWN, Warszawa 1979, s. 193-231.

Życiński Stanisław, Złotnictwo w skarbcach magnatów i szlachty polskich ziem koronnych w Rzeczypospolitej XVII-XVIII wieku. Broń biała, rzędy końskie, srebra, klejnoty, Wydawnictwo Naukowe Uniwersytetu Szczecińskiego, Szczecin 1990.

Biog ram: Anna Penkała-Jastrzębska, doktor nauk humanistycznych. Zatrudniona na stanowisku adiunkta w Instytucie Historii i Archiwistyki Uniwersytetu Pedagogicznego im. Komisji Edukacji Narodowej w Krakowie. Badawczo zainteresowana problematyką majątkowych aspektów zawierania małżeństw przez przedstawicieli rodzin szlacheckich, a także sprawami procesowymi i sferą kultury materialnej badanymi w oparciu o księgi grodzkie dawnego województwa krakowskiego; kontakt: anna.penkala-jastrzebska@up.krakow.pl. 